\title{
A MULTI-CRITERIA INDEX FOR WETLAND RECONSTRUCTION SITE SUITABILITY IN ONTARIO'S MIXEDWOOD PLAINS
}

\author{
By \\ Sarah Medland, \\ Honours Bachelor of Arts in Geographic Analysis, Ryerson University 2018

\begin{abstract}
A Major Research Paper presented to Ryerson University
in partial fulfillment of the requirements for the degree of

Master of Spatial Analysis (MSA)

in the program of

Spatial Analysis
\end{abstract}

Toronto, Ontario, Canada, 2019

(C) Sarah Medland, 2019 


\section{Author's Declaration}

I hereby declare that I am the sole author of this MRP. This is a true copy of the MRP, including any required final revisions.

I authorize Ryerson University to lend this MRP to other institutions or individuals for the purpose of scholarly research.

I further authorize Ryerson University to reproduce this MRP by photocopying or by other means, in total or in part, at the request of other institutions or individuals for the purpose of scholarly research. I understand that my MRP may be made electronically available to the public. 
Sarah Medland

Master of Spatial Analysis (MSA), Ryerson University

2019

Abstract

Significant wetland loss in Ontario has resulted in the loss of important ecosystem services which help to mitigate the effects of global change. This research aimed to create a multi-criteria index for identifying where suitable sites for wetland reconstruction are spatially distributed in Ontario's Mixedwood Plains. The index is intended as a decisionmaking tool for reaching wetland reconstruction goals such as those outlined by the Ontario MNRF's plan to restore historically lost wetland area and function. By incorporating ecosystem services, the index will indicate areas where wetlands would be most beneficial. The resulting index generated a raster with a range of suitability based on seven criteria. Soil drainage and Agriculture were the most important criteria and weighed most heavily in the index. Overlay analysis indicated that suitable sites were clustered in areas which had historically undergone wetland loss or are areas of existing wetlands. 


\section{Acknowledgments}

I would like to thank my supervisor Dr. Richard R. Shaker for his suggestions and guidance throughout my undergraduate years and the writing of this Major Research Paper. I would also like to thank Dr. Wayne Forsythe for his recommendations.

Lastly, I would like to thank my loved ones for their continuing support and encouragement, most specifically, Anna Brooker for working by my side throughout the MSA program. 


\section{Table of Contents}

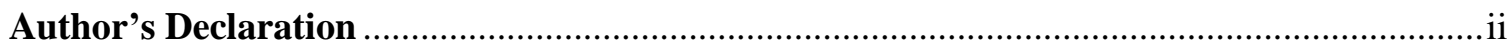

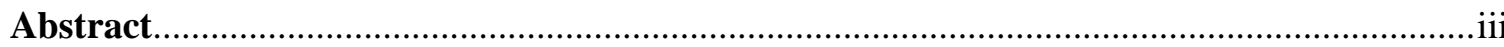

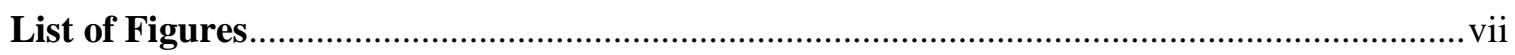

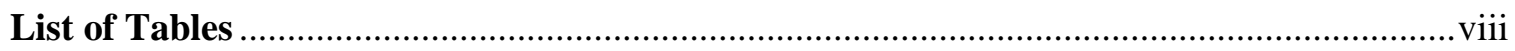

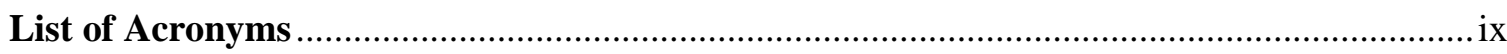

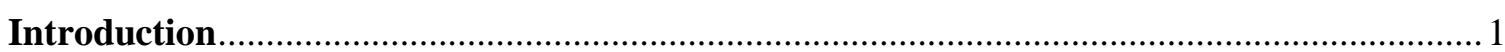

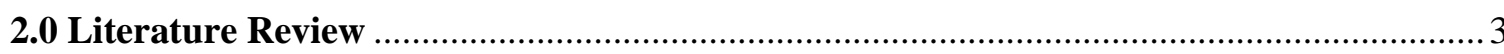

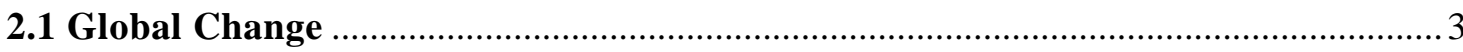

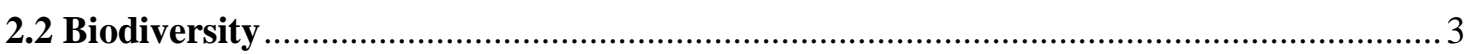

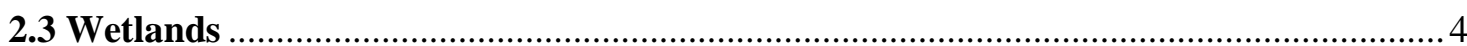

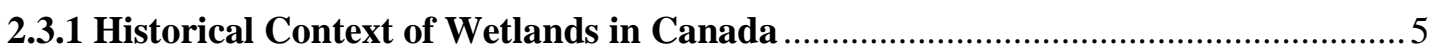

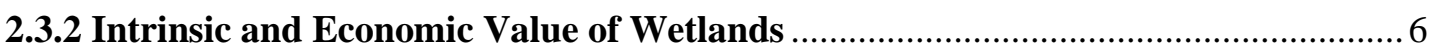

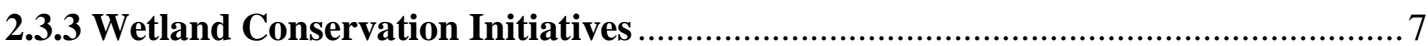

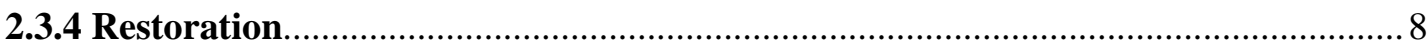

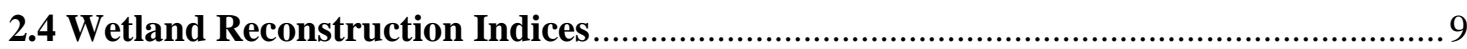

2.4.1 Wetland Indices - Potential Variables........................................................... 9

2.4.2 Wetland Indices - Methodological Framework .................................................... 11

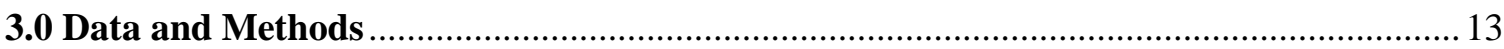

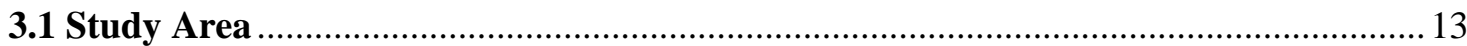

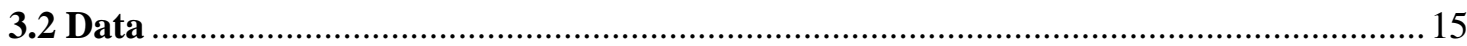

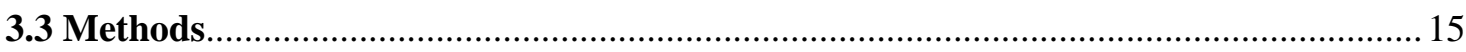

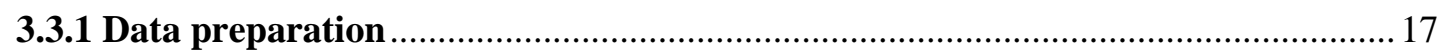

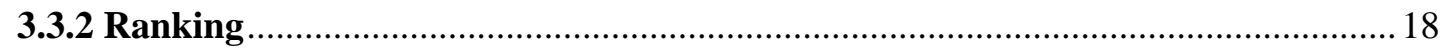

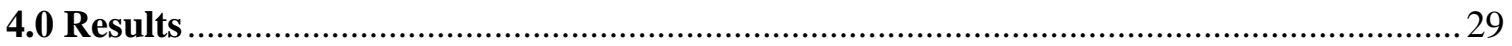

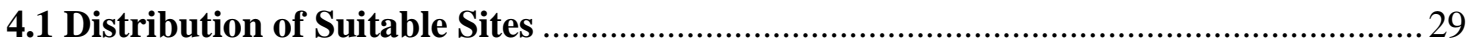

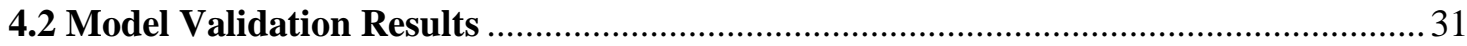

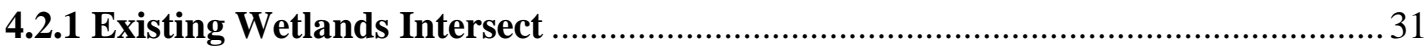

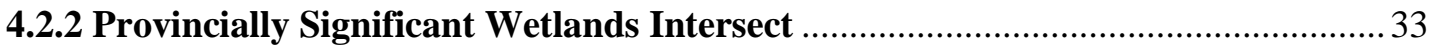

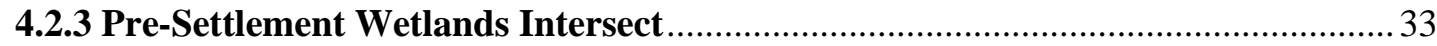

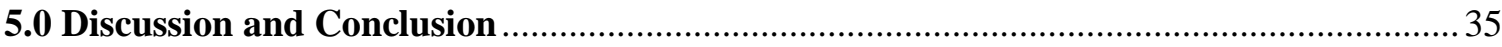

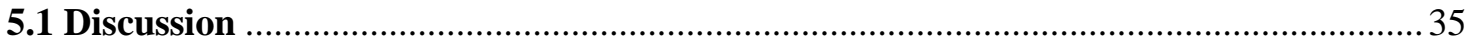

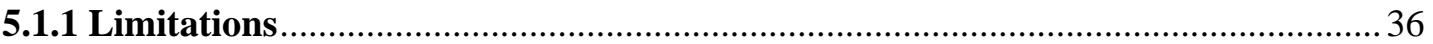




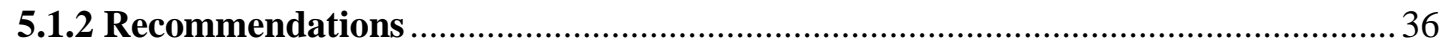

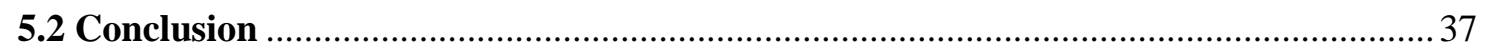

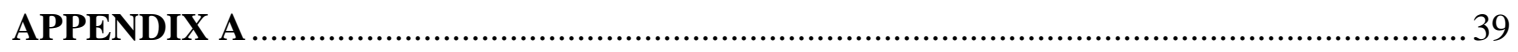

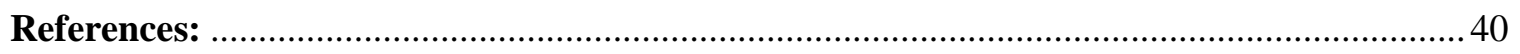




\section{List of Figures}

Figure 3.1: Study Area: Ontario's Mixedwood Plains by census subdivision............................ 144 Figure 3.2: Methods processing from transforming raw data to derived criteria, the generation of the suitability index, model validation, and results..... 166

Figure 3.3: Spatial Distribution and Assigned Values: a. Slope (degrees), b. Agriculture............ 21 Figure 3.4: Spatial Distribution and Assigned Values: c. Built-up, d. Soil Drainage

Figure 3.5: Spatial Distribution and Assigned Values: e. Groundwater level (m), f. Stream

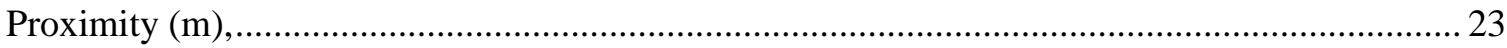

Figure 3.6: Spatial Distribution and Assigned Values: g. Major Water Bodies ............................ 24

Figure 4.1: Mixedwood Plains Wetland Reconstruction Site Suitability ..................................... 31 Figure 4.2: Wetland Site Suitability - Most Suitable Sites / and Existing Wetlands intersect by

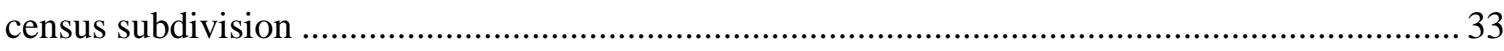
Figure 4.3: Wetland Reconstruction Site Suitability-Most Suitable Sites/ OWES Provincially Significant Wetland Comparison. 34 Figure 4.4: Wetland Reconstruction Site Suitability - Most Suitable Sites/DUC 1800s Historic Wetlands Comparison. 35 


\section{List of Tables}

Table 3.1: Selected data and sources for Mixedwood Plains wetland reconstruction index.......... 15

Table 3.2: Criteria Goals and Pre-Processing .......................................................................... 17

Table 3.3: Saaty's Reciprocal Importance Scale (1977) and relationship to literature "count" ..... 25

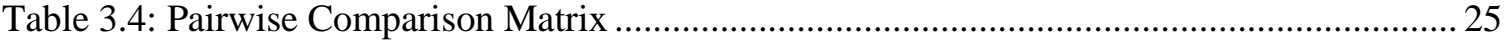

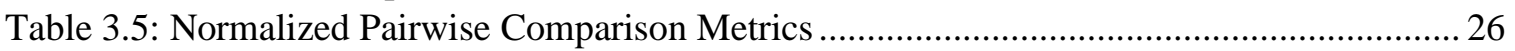

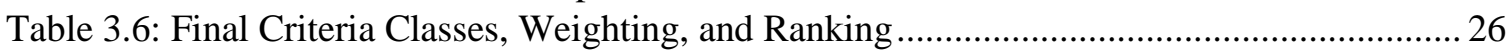




\section{List of Acronyms}

\section{AHP}

Analytical Hierarchy Process ………………………………...................................................................... 24

ARI

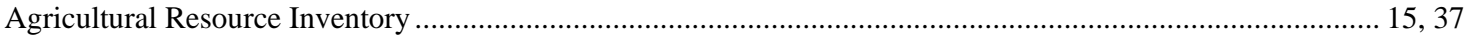

CI

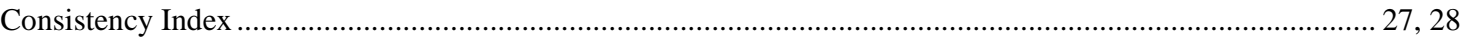

CLI

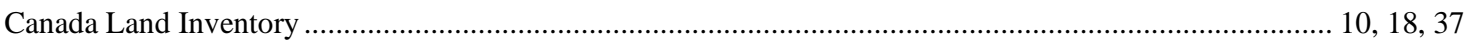

CR

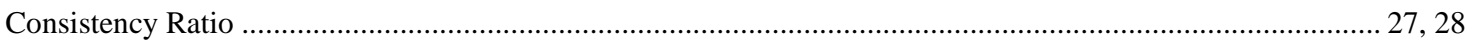

DSS

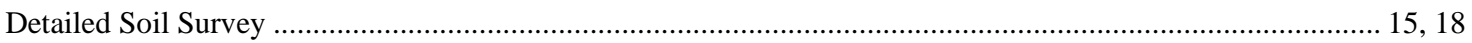

DUC

Ducks Unlimited Canada ............................................................................................... vii, 6, 7, 29, $35,36,37$

ECCC

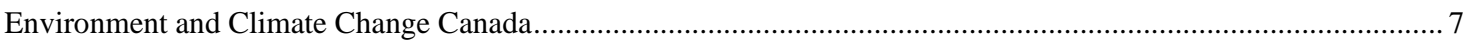

GIS

Geographic Information System ................................................................................. 1, 4, 8, 9, 38, 42, 44

MCE

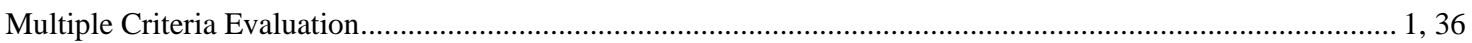

MNRF

Ministry of Natural Resources and Forestry........................................................... 1, 4, 5, 6, 7, 8, 13, 14, 36, 38

OWES

Ontario Wetland Evaluation System

vii, 29,34

PGMN

Provincial Groundwater Monitering Network ................................................................................. 15, 19

PWA

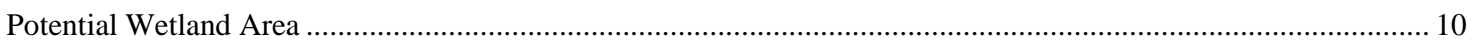

RI

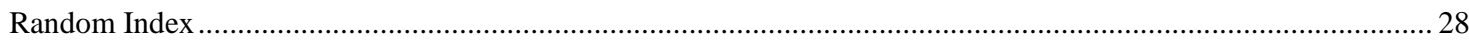




\section{Introduction}

As the effects of global change have become increasingly threatening, the need to understand and mitigate these effects increase. One major aspect of global change is land cover change. Throughout history, Ontario has undergone significant land cover change in favour of development. Wetlands in particular were previously regarded as territory which was useless until transformed, resulting in a 72\% decrease in wetland area (Classens, 2018; Giblett, 2014; Ducks Unlimited Canada, 2010). This is a serious loss, as a wetland's ability to provide habitat, flood mitigation, water filtration and more, have become more valuable with worsening effects of climate change. However, wetlands can be reconstructed to a variety of degrees and functions, allowing their important ecosystem services to be integrated back into the landscape.

Wetland loss in Ontario is the result of many planning decisions in favour of agriculture, or industrial and residential development over natural areas. The Ontario MNRF (Ministry of Natural Resources and Forestry) plans to halt and reverse this process (Ontario MNRF, 2017). In order to better plan for large scale changes, GIS (Geographic Information Systems) can be used to facilitate quick, replicable, quantitative, decisionmaking tools. The use of MCE (Multiple Criteria Evaluation) allows for the consideration of many variables at once. These may include any biophysical or ecosystem service indicators, which represent best possible sites for wetland reconstruction. Multi-criteria indices integrated with GIS have been used to predict most suitable sites for a variety of projects. 
This research aims to understand which areas are best suited for wetland rehabilitation in Ontario's Mixedwood Plains in order to maximize ecosystem services and minimize effort by answering the following research questions:

- Which criteria indicate high suitability for wetland reconstruction? Which are most important?

- Physical characteristics

- Indicators of need for ecosystem services

- Where have wetlands previously been removed from the landscape and are these spaces still appropriate for present day wetlands?

- Where are areas of low to high suitability spatially distributed? 


\subsection{Literature Review}

\subsection{Global Change}

With growing intensity and speed, the Earth is undergoing a massive environmental transformation best described as global change. Global change can be attributed to anthropogenic factors such as resource extraction, growing infrastructure footprint, and land conversion (Venter et al., 2016). This transformation can largely be summarized into two overarching categories: climate change, and land cover change. Climate change is a phenomena which can be observed from local to global scales (Lovejoy et al., 2019). Not exclusively limited to the warming of the atmosphere, its effects are felt in seasonal changes, increased storm frequency and intensity, and increased precipitation (Lovejoy et al., 2019).

Land cover change occurs when an area is repurposed for another land use; such as agriculture or urban development. The original land cover is changed resulting in alterations to natural hydrology and landscape composition. Land cover change has the potential to impact remaining unchanged ecosystems negatively through the nature of habitat fragmentation. Habitat fragmentation results in habitats that may be too small, isolated or lacking in connectivity to sustain their original populations following land cover change (Haddad et al., 2015). Increasingly advanced GIS has allowed researchers to better understand the spatial patterns in global change and the how climate and land use changes may impact the natural world (Haddad et al., 2015).

\subsection{Biodiversity}

The combination of climate change, land cover change, and in turn, habitat loss, is largely understood to be a major driver in decreasing biodiversity worldwide (Bellard et 
al., 2014; Yalcin \& Leroux, 2018;). Consequently, biodiversity is a major indicator of environmental integrity (Shaker et al., 2017). All organisms thrive under specific habitat conditions which are required for their success (Lovejoy et al., 2019). In the event of change, species will shift their habitat in favour of these preferred conditions (Haddad et al., 2015). However, empirical evidence on the relationship between species diversity and global change is rare (Bellard et al., 2014).

Attempts to quantify land cover and climate change using GIS, help to demonstrate how global change specifically impacts biodiversity. A study by Yalcin \& Leroux (2018) examined the correlation between Ontario bird population extinction and colonization with factors such as temperature, precipitation, and physical land-cover change. They found that the combination of both land cover change and climate change resulted in higher colonization and colony extinction among species (Yalcin \& Leroux, 2018). On a larger scale, a study conducted which focused on 34 vulnerable biodiversity hotspots, identified climate change using dissimilarity analysis and historic climate records (Bellard et al., 2014). It was found that biodiverse areas were more vulnerable to climate dissimilarities and may shrink over time as a result. Overall, there is a growing need to understand both the impacts and spatial distribution of land cover change, climate change, and biodiversity loss (Lovejoy et al., 2019).

\subsection{Wetlands}

Accounting for numerous unique habitats, wetlands are one of the most biodiverse land cover types on Earth (Ontario MNRF, 2017). By definition, wetlands are poorly drained areas in which land is saturated long enough to sustain aquatic organisms. They are classified into 5 categories: bogs, fens, marshes, swamps, and shallow water based on 
physical properties (National Wetlands Working Group, 1987). Wetlands provide many ecosystem services including habitat, water quality improvement, nutrient cycling, recreation, groundwater recharge, and erosion reduction (Sivakumar \& Ghosh, 2016; Ontario MNRF, 2017).

Wetlands are impacted by global change in many ways. All over the world they have been converted in favour of development for other needs (Huang et al., 2010; Odgaard et al., 2017). Their structure and area is impacted by land cover change as the result of dredging and filling, eutrophication, alterations to hydrology, and surface runoff (Klemas, 2011). The increasing footprint of cities and infrastructure have increased the levels of nitrogen and phosphorus throughout surface water and soil. Climate change has slowed groundwater recharge, increased bacterial growth, and lowered precipitation overall (Sivakumar \& Ghosh, 2016). With approximately 150 million hectares of wetland, Canada holds nearly one quarter of these important ecosystems - a larger area than anywhere in the world (Giblett, 2014; National Wetlands Working Group, 1987). Due to their prominence in the Canadian landscape and their overall contribution to biodiversity, it is important to understand the current state of wetland loss in Canada and the historical context which led to it.

\subsubsection{Historical Context of Wetlands in Canada}

Wetlands in the Canadian landscape have a long history of being regarded as peripheral spaces. These important regions played a role in the lives of Indigenous Canadians for thousands of years, however these same wetlands have been largely overlooked by Canadians post-settlement (Giblett, 2014). From the current cultural perspective, wetlands are often considered vague, undefined areas which lie ambiguously 
between land and water though they encompass both. These spaces are rarely included in iconic images of Canadian wilderness and recreation; which are more likely to include forests, mountains, and lakes. Wetlands lie in between and on the perimeter of these land features. The cultural discourse of wetlands is that they are not preferred to these pristine ideas of wilderness, as the historically constructed idea of wetlands has been of muddy, impassable, and useless territory (Classens, 2017; Giblett, 2014). This idea carried over into the practical treatment of wetlands in the Canadian landscape throughout time.

During European settlement in Ontario, wetlands were regarded as wasteland to be converted into arable land or other developments (Classens, 2018). Since this time, $72 \%$ (or 1.4 million hectares) of wetlands in Ontario have been eliminated by means of land cover change, mostly to intensive agriculture (Snell, 1987; Ducks Unlimited Canada, 2010). This loss is concentrated in Southern Ontario, where population is highest and industry most abundant (Ducks Unlimited Canada, 2010; Ontario MNRF, 2017). Simply put, wetlands were not able to compete economically with other land uses in Ontario, and therefore have been steadily replaced in favour of privatized and industrialized land (Ducks Unlimited Canada, 2010; Snell, 1987).

\subsubsection{Intrinsic and Economic Value of Wetlands}

Throughout history, the disappearance of wetlands has often been in favour of economic development. This meant the transformation of wetlands into areas which could produce profit or lend way to infrastructure. Classens (2018) aims to understand how the natural environment fits into the equation of private property and economic value by analyzing the ownership of natural resources. Through the investigation of the loss of Holland Marsh, a section of land famously drained and converted to agricultural fields in 
Southern Ontario; Classens (2018) states that the privatisation of biophysical nature comes with a need for a certain aspect. The muck soil present beneath many wetland's surface water has been seen as a growing medium to be distributed and owned since the time of colonial settlement (Classens, 2018). The use of this resource involved investment into the transformation of wetlands into another land use. Until recently, this action of transformation was the only way in which wetlands could be viewed as valuable.

Once considered an obstacle to development, wetlands are now viewed as assets to the landscapes they occupy. Their desirability has moved beyond their potential to transform as the intrinsic value of wetlands in their natural condition is recognized. As climate change introduces increasingly frequent and severe weather events, a wetland's ability to mitigate floods becomes more valuable. Their capacity to stabilize soil and improve water quality through natural filtration is an important quality with increasing industrialization of agriculture and spread of infrastructure. They are habitats to a variety of species, and provide spaces for tourism and recreation (Ontario MNRF, 2017). The aforementioned ecosystem services were removed with the massive transformation of wetlands throughout Canadian history. As the need for the return of these services grows with the effects of global change, efforts towards conservation and reconstruction are introduced into Canadian policy.

\subsubsection{Wetland Conservation Initiatives}

The disappearance of these valuable spaces has not gone unnoticed. Organizations such as DUC (Ducks Unlimited Canada), ECCC (Environment and Climate Change Canada), and the Ontario MNRF, have contributed research of this issue with a working goal to restore wetlands back into Ontario's landscape. Major non-profit and government 
agencies have recently set goals to halt this loss and work to restore wetlands to their original condition. Most recently, the Ontario MNRF created A Wetland Conservation Strategy for Ontario 2017-2030 as a framework for wetland restoration in Ontario (Ontario MNRF, 2017). The strategy involves two main goals to measure its success:

1. By 2025, the net loss of wetland area and function is halted where wetland loss has been the greatest.

2. By 2030, a net gain in wetland area and function is achieved where wetland loss has been the greatest.

In 1987, Environment Canada began to put efforts toward understanding wetland distribution and wetland loss nationwide (Ducks Unlimited Canada, 2010; Snell, 1987). Since this time, more complete datasets have built upon these original efforts with increasing accessibility to advanced and accurate GIS technology. In 2010, DUC (a nonprofit dedicated to wetland conservation) built extensive research upon this original dataset, creating a spatially accurate pre-1800s wetland extent to illustrate the massive change in land use in Ontario. This dataset provides quantitative evidence for the spatial distribution of wetland loss in Ontario's Mixedwood Plains. As anthropogenic effects continue to be a powerful stressor on the environment in Southern Ontario, wetland restoration initiatives become more relevant. Spatial datasets such as historic, present, and potential wetland extents help to focus restoration efforts more effectively.

\subsubsection{Restoration}

Wetland restoration involves returning a landscape back into some form of its natural condition (Klemas, 2011). The purpose of a wetland restoration project may be for 
any of the following reasons: creating new habitat, increasing water retention, decreasing sediment, or diminishing nitrogen and phosphorus from agricultural inputs (DarwicheCriado, et al., 2017). Wetland restoration can involve the removal of fill and invasive plants, elevation grading, creation of appropriate channels, and the introduction of new vegetation. In some cases, trails, bridges, boat ramps and other infrastructure may also be introduced to encourage recreation in the constructed wetland (Klemas, 2013). Each restoration differs based on the goals, budget, timeline, and the present state of the area at the time of restoration. The quality of the finished product may vary as well due to these factors.

\subsection{Wetland Reconstruction Indices}

The use of GIS and remote sensing allows for timely and cost-effective decision making. MCE allows for smart allocation of sustainable development efforts by considering many economic and ecological factors at once. (Klemas, 2013; Shaker \& Sirodoev, 2016). Indices are a useful tool for facilitating consistent, quantitative decisionmaking over a large surface (Shaker \& Sirodoev, 2016). They help to provide insight over

a large-scale area, eliminating the need for project-by-project analysis (White \& Fennessy, 2005). Wetland reconstruction indices have proven successful in identifying ideal wetland sites in other regions which have undergone similar land cover changes; however, such an index does not yet exist for Southern Ontario.

\subsubsection{Wetland Indices - Potential Variables}

Wetland reconstruction indices largely focus on identifying biophysical variables already present such as those which would best support a wetland. In 1987, Environment Canada created the first comprehensive study on wetland conversion in Southern Ontario 
using biophysical variables and existing land use maps to determine the spatial distribution of wetlands (Snell, 1987). The CLI (Canadian Land Inventory) soil maps were used to determine current and past wetlands through mapping organic soils, and varying degrees of poorly drained soils (Snell, 1987). This same updated data will be used in this study for continuity. A study by Horvath et al. (2017) conducted in the contiguous United States, an indicator of PWA (Potential Wetland Area) was created using poorly drain soils, low relief landscape, and existing wetlands as the criteria (Horvath et al., 2017). Other wetland index studies also prioritized slope, proximity to watercourses, agricultural land, groundwater levels, soil permeability, availability of public lands, and socio-economic factors (Darwiche-Criado et al., 2017; Huang et al., 2010; Sivakumar \& Ghosh, 2016). White \& Fennessy (2005) included existing wetlands to increase size and connectivity of habitats as well as to further control point-source pollution.

In order to best make use of wetland ecosystem services, it is beneficial to include these services in the site selection index as well. Wetlands in Denmark have undergone a similar transformation to those in Ontario- over $70 \%$ of these wetlands have disappeared the $19^{\text {th }}$ century to create room for development. A multi-criteria index developed in Denmark quantified ecosystem services, not by mapping the services themselves but rather where they would be most needed development (Odgaard et al., 2017). For example, the variable "flash flood risk" was calculated using the area of buildings potentially flooded from a 100-year flood event. This index also included ecosystem service indicators such as: recreation potential, biodiversity, nitrogen mitigation potential, and inverse land rent (Odgaard et al., 2017). Through a different strategy Horvath et al. (2017) conducted overlay analysis following the creation of the index with areas of need such as waterfowl habitat 
or agriculture. By including areas in need of a particular ecosystem service, the ecosystem service can be mapped and accounted for in quantitative nature. This study will include areas in need of flood mitigation and prioritize agricultural areas which are generally in need of water filtration, and increased biodiversity.

\subsubsection{Wetland Indices - Methodological Framework}

After determining the required variables, the spatial data must be combined in a uniform manner for analysis. This strategy is to facilitate overlay analysis as well as the understanding of the spatial distribution of each variable individually (Sivakumar \& Ghosh, 2016). Ghosh and Sivakumar (2016) created a thematic spatial database of physical wetland characteristics to identify wetland area change over a $350 \mathrm{~km}^{2}$ area. Horvath et al. (2017) transformed each biophysical layer from vector to 30m grid rasters to allow for aligned grid cell by grid cell analysis. In the forthcoming study, a 50m raster will be used to represent each criterion and facilitate the summation of these weighted and ranked criteria.

Once the variables are determined, each sub-class is reclassified to scores (or ranks) based on its suitability to wetland restoration. Then, each criterion is weighted ranging from lowest to highest suitability based on their relative importance (Darwiche-Criado et al., 2017; Sivakumar \& Ghosh, 2016). Odgaard et al. (2017) accounted for variables in their rankings which they believed were undervalued in previous wetland reconstruction projects. Other studies determined which biophysical properties were more crucial than

others when considering a wetland reconstruction site. Ranking may include a numeric range of suitability or "restricted" subclasses such as a "built-up" land cover type (Sivakumar \& Ghosh, 2016; White \& Fennessy, 2005). By combining each ranked and 
weighted variable in an index, a unique value of wetland reconstruction potential may be determined for each spatial unit. 


\subsection{Data and Methods}

\subsection{Study Area}

For the purpose of this research, the boundary of the Ontario Mixedwood Plains ecozone will define the study area (Figure 3.1). Despite suffering a significant loss in wetland area, Ontario is home to six percent of the Earth's total wetland area (Ontario MNRF, 2017). The Mixedwood Plains ecozone encompasses Southern Ontario below the Hudson's Bay Lowlands and the Ontario Shield ecozones. This ecozone is approximately $8,484,861$ ha. Largely shaped by glacial movement, the landscape has unique features above and below surface such as groundwater features, moraines, and the Niagara escarpment (Bradford, 2016).

The Mixedwood Plains is the most populous and industrious ecozone in Ontario. As a result, it has seen the largest loss in wetlands, which in turn affects the largest population of Ontarians. This loss can be attributed to land use change to create room for industrial, residential, and agricultural spaces (Ducks Unlimited Canada, 2010; Ontario MNRF, 2017). The loss of wetlands to development is significant across Ontario's landscape, however it is the result of many small development decisions in favour of other land types, rather than the result of overarching planning (Bradford, 2016). This creates a need for more careful planning from a large-scale perspective in order to understand impacts on landscape composition, prevent habitat fragmentation, and restore larger wetland patches (White \& Fennessy, 2005). This phenomenon, in combination with the 
MNRF goals to protect and restore Ontario's wetlands makes the Mixedwood Plains an ideal study area for a multi-criteria wetland reconstruction index.

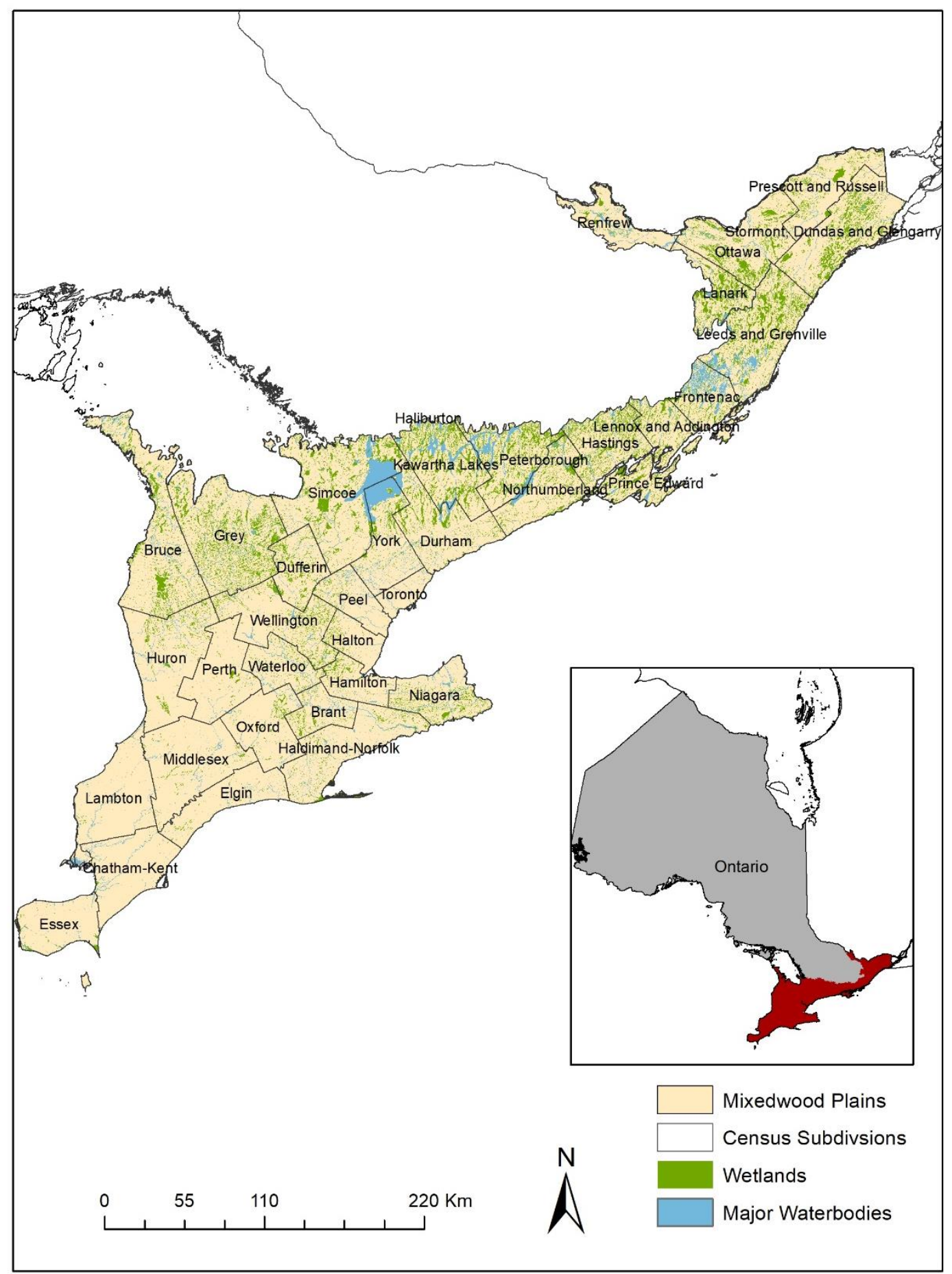

Figure 3.1: Study Area: Ontario's Mixedwood Plains by census subdivision 


\subsection{Data}

Growing concerns of wetland loss in the Mixedwood Plains has resulted in a significant compilation of datasets comprising of relevant biophysical features. In efforts to best model the current condition of the Mixedwood Plains landscape, the most current, complete data, at the smallest possible resolution were selected (Table 3.1). Biophysical variables present in similar wetland indices such as soil drainage, groundwater level, slope, and hydrology were considered when selecting data for the reconstruction index. In addition, benefits of ecosystem services to agricultural land, such as flood mitigation, water filtration, and biodiversity were also considered.

Table 3.1: Selected data and sources for Mixedwood Plains wetland reconstruction index

\begin{tabular}{|c|c|c|c|c|}
\hline Data & Derived Variable & Resolution & Source & Year \\
\hline $\begin{array}{l}\text { ARILand } \\
\text { Use }\end{array}$ & Agriculture & $50 \mathrm{~m}$ & $\begin{array}{l}\text { Agricultural Resource Inventory (ARI) -Ontario } \\
\text { Ministry of Agriculture, Food, and Rural Affairs }\end{array}$ & $\begin{array}{l}1983- \\
2010\end{array}$ \\
\hline $\begin{array}{l}\text { Built-up } \\
\text { Area }\end{array}$ & Built-up Area & $15 \mathrm{~m}$ & $\begin{array}{l}\text { Built-up Area - Ontario Ministry of Natural } \\
\text { Resources (OMNR) }\end{array}$ & 2013 \\
\hline Roads & Built-up Area & $10-50 \mathrm{~m}$ & Major Roads Network- DMTI Spatial & 2018 \\
\hline Wetlands & Existing Wetland & $50 \mathrm{~m}$ & Wetland Unit - Land Inventory Ontario (LIO) & \\
\hline Well-Depth & Groundwater level & N/A & $\begin{array}{l}\text { Provincial Groundwater Monitoring Network } \\
\text { (PGMN)- Ministry of Environment }\end{array}$ & 2016 \\
\hline $\begin{array}{l}\text { Major } \\
\text { Waterbodies }\end{array}$ & Major Waterbodies & $5-30 \mathrm{~m}$ & Waterbodies Region - DMTI Spatial & 2018 \\
\hline DEM & Slope & $30 \mathrm{~m}$ & DEM90 Digital Elevation Model - EarthEnv & 2014 \\
\hline Soil Type & Soil Drainage & $50 \mathrm{~m}$ & $\begin{array}{l}\text { Canadian Land Inventory - Detailed Soil Survey } \\
\text { (DSS) Compilations }\end{array}$ & 2010 \\
\hline $\begin{array}{l}\text { Stream } \\
\text { Network }\end{array}$ & Proximity to Streams & $10 \mathrm{~m}$ & $\begin{array}{l}\text { Ontario Ministry of Natural Resources - Ontario } \\
\text { Hydro Network (OHN) }\end{array}$ & 2010 \\
\hline
\end{tabular}

\subsection{Methods}

Geospatial data for each variable of wetland suitability were transformed to uniform raster surfaces for the creation of a thematic database. Using relevant literature and multicriteria evaluation, weighting and ranking was applied to describe each variable's suitability and relative importance to wetland restoration in the study area (Sivakumar \& Ghosh, 2016; White \& Fennessy, 2005). Each raster cell was consequently assigned a value 
of suitability for each variable based the resulting index. When summed, the final raster surface provided a range of wetland reconstruction site suitability based on the aforementioned criteria. This surface was validated using overlay analysis with presentday provincially significant wetlands, and historic pre-settlement wetlands (Figure 3.2).

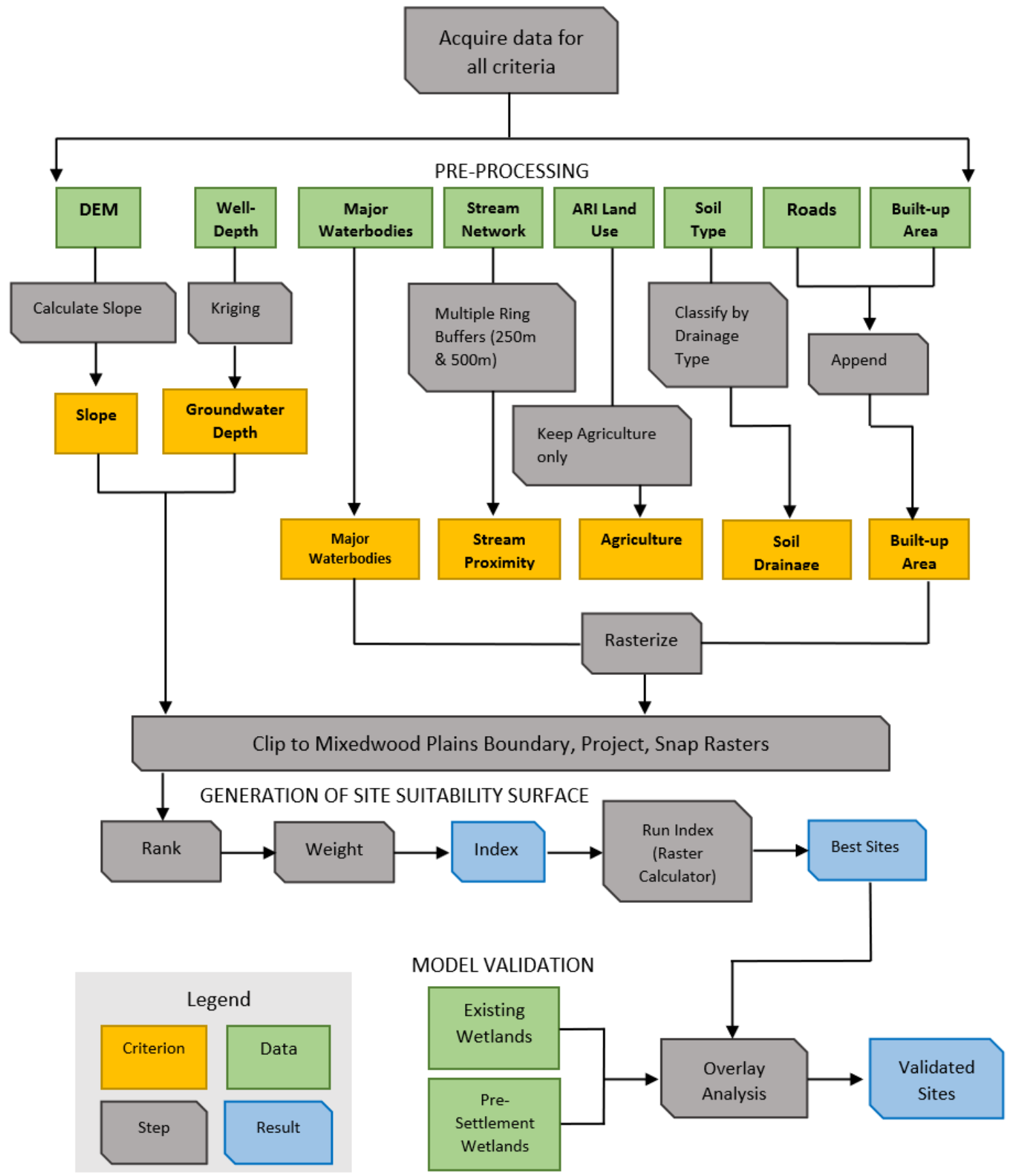

Figure 3.2: Methods processing from transforming raw data to derived criteria, the generation of the suitability index, model validation, and results 


\subsubsection{Data preparation}

For the purpose of this study, a raster data type was chosen as the medium for creating the reconstruction suitability index. Raster data allows for a pixel by pixel comparison of a landscape, allowing for finer resolution results than vector boundaries. For the purpose of this study, each variable was resampled to $50 \mathrm{~m}$, the lowest resolution of the selected data (Table 3.1). This resolution provides the most detail without oversimplifying larger resolution data. For policy and planning purposes, using the finest resolution creates more useful results to be used a different scales (Odgaard et al., 2017). In ArcGIS Pro, each variable was processed using Model Builder to ensure uniform parameters such as projection, snap raster, and resolution. Variables underwent differing geoprocessing in order to ensure they represented the engineering goals (Table 3.2).

Table 3.2: Criteria Goals and Pre-Processing

\begin{tabular}{|c|c|c|}
\hline Variable & Goal & Pre-Processing \\
\hline Agriculture & Prioritize conversion & $\begin{array}{l}\text { Clip, Select and Export Agriculture only, } \\
\text { Rasterize }\end{array}$ \\
\hline Built-up Area & Avoid & Clip, Rasterize, Append "roads" to "built-up" \\
\hline Existing Wetland & Validate model & Clip, Rasterize \\
\hline Groundwater level & Prioritize shallow & Interpolate Surface (Kriging), Clip \\
\hline Major Waterbodies & Avoid major lakes and streams & Clip, Rasterize \\
\hline Slope & Prioritize gentler slopes & $\begin{array}{l}\text { Mosaic, Clip, Run Slope on DEM, Aggregate } \\
\text { Classes }\end{array}$ \\
\hline Soil Drainage & $\begin{array}{l}\text { Prioritize soils which are naturally } \\
\text { more similar to wetlands and avoid } \\
\text { those with rapid drainage Prioritize in } \\
\text { areas which are prone to flooding }\end{array}$ & Clip, Rasterize, Aggregate Classes \\
\hline Stream Proximity & Prioritize closer proximity to streams & Clip, Run $250 \mathrm{~m}$ and $500 \mathrm{~m}$ buffers, Rasterize \\
\hline Road Network & Avoid & Clip, Rasterize, Append "roads" to "built-up" \\
\hline
\end{tabular}




\subsubsection{Ranking}

Raster analysis allows for each grid cell to have an assigned value for each criterion. This simplistic method works for quantifying the cell's relative suitability for a wetland reconstruction project (White \& Fennessy, 2005). To normalize the pixel values for all 7 variables, each raster was reclassified to a ranking system of 0-4 (from least to most suitable for wetland reconstruction, respectively). Ranking was determined by referencing relevant literature on appropriate biophysical properties for wetland reconstruction (DarwicheCriado et al., 2017; Horvath et al., 2017; Odgaard et al., 2017; Sivakumar \& Ghosh, 2016; White \& Fennessy, 2005).

Wetlands require flat or gently sloping topography in order for water to collect (Darwiche-Criado et al., 2017; Horvath et al., 2017; White \& Fennessy, 2005). Most slope values in the study area met this criterion. Slope ranged from 0-41.54 degrees with a mean of only 1.12 degrees. Natural Breaks (Jenks) was used to classify slope into natural classes to account for the skewed distribution. The resulting 3 classes for ranking were as follows: $<1.5,1.5-4.5$, and $>4.5$ (Figure 3.3).

As wetlands often consist of poorly drained soils, these are often prioritized in suitability models (Horvath et al., 2017; Odgaard et al., 2017; Sivakumar \& Ghosh, 2016). The DSS (Detailed Soil Survey) from the CLI contained updated data from previous CLI soil surveys. These data are an updated version of that used by Snell (1987) to create the first wetland inventory in Ontario. Additionally, DUC (2010) utilized the CLI soil survey to identify poorly and very poorly drained soils as indicators of historic wetlands. By using a current soil survey and ranking poorly, and very poorly drained soils highest, consistency can be maintained with these previously conducted studies (Tables 3.1 \& 3.2) (Figure 3.4). 
In addition, frequently inundated soils were included among the "Very poorly drained" soil class. This helps to prioritize flood mitigation properties to sites which need it most.

To prioritize closer proximity to streams, buffers were placed around an Ontario Hydro Network stream file (2010). Darwiche-Criado (2017) and Huang et al., (2010) used $500 \mathrm{~m}$ as the threshold for closeness to streams in their wetland site selection processes. As freshwater streams are abundant the Mixedwood Plains region, and most pixels were within $500 \mathrm{~m}$ of a stream network, a $250 \mathrm{~m}$ stream buffer was applied as well. Pixels falling in buffers nearer to streams ranked higher (Figure 3.5).

Sivakumar \& Ghosh (2016) prioritized shallower groundwater in their overlay analysis wetland mitigation plan. For the purpose of this study, a groundwater surface was interpolated using the PGMN (Provincial Groundwater Monitoring Network). These data consisted of 367 points. Kriging was used to interpolate a continuous raster surface for the PGMN points (Khalili, 2014; Kumar \& Remadevi, 2006). In addition to the interpolated surface, kriging produces an output variance layer, which unlike other interpolation methods, provides the user with the confidence values of the predicted pixel values. The resulting groundwater surface could then be reclassified into depth classes for ranking (Figure 3.5)

Some variables required only 2 classes (acceptable, and not acceptable). These variables may be referred to as constraints in the model, while other variables of varying suitability are referred to as "factors" (Atkinson, et al., 2005; White \& Fennessy, 2005). For constraint variables such as the Built-up variable, a value of "0" was assigned to roads, buildings, and paved surfaces, whilst the rest of the pixels were given a "1". This ensures that constraint variables will have the lowest values when combined in the final index, and 
high scoring sites will not be placed on impervious surfaces, infrastructure, or permanent water bodies (Figures 3.3 - 3.6). 
a.

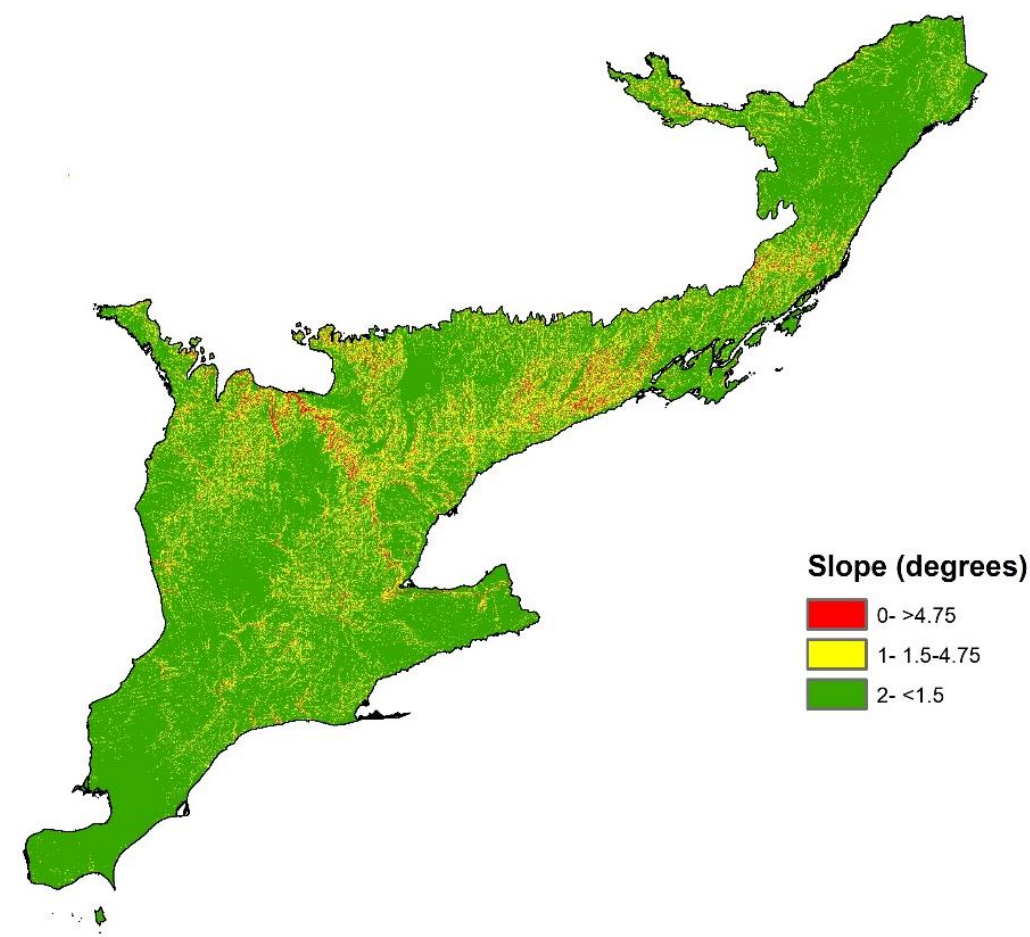

b.
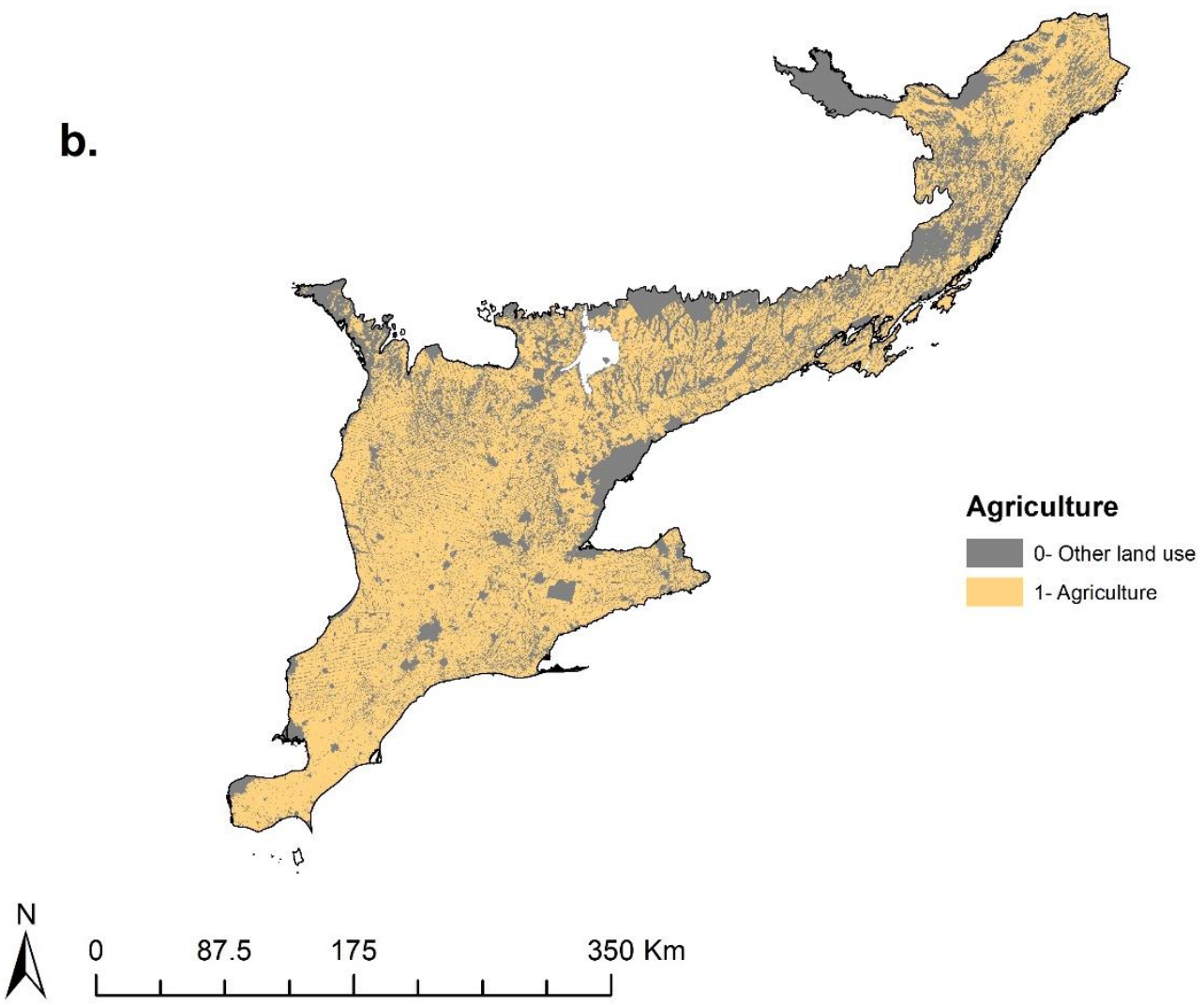

Figure 3.3: Spatial Distribution and Assigned Values: $a$. Slope (degrees), b. Agriculture 
c.

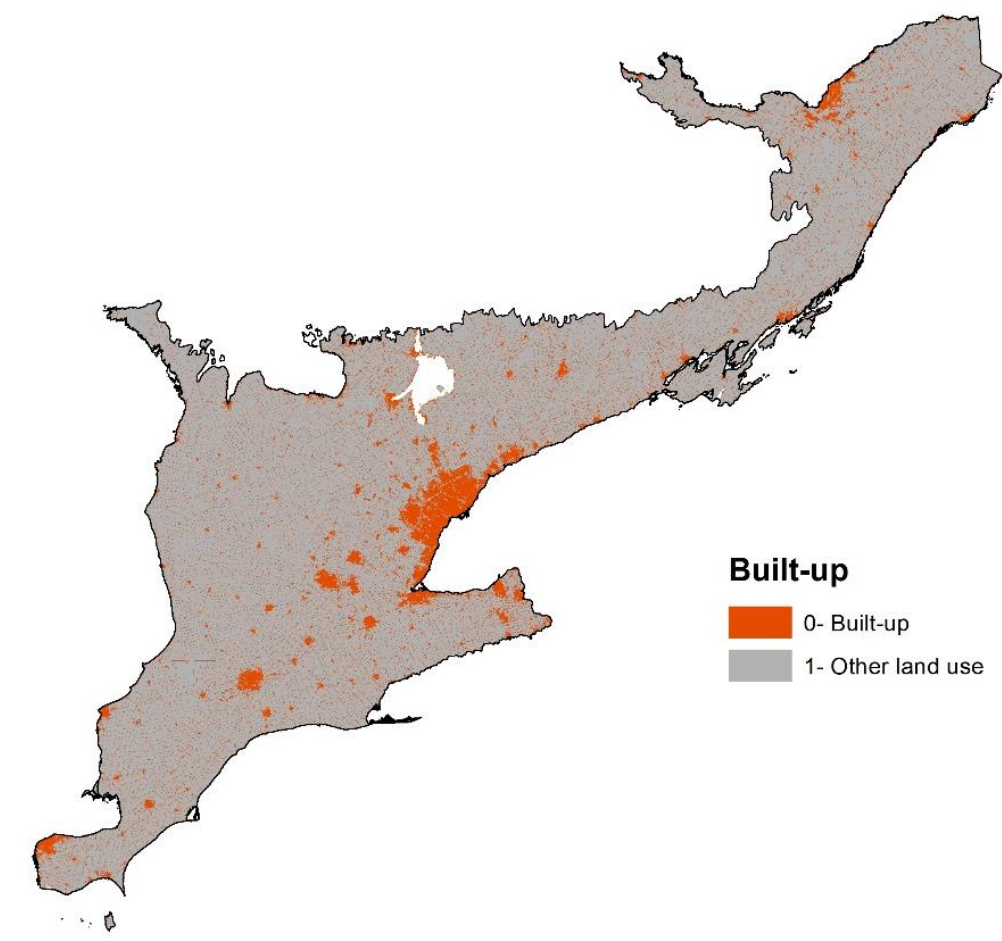

d.
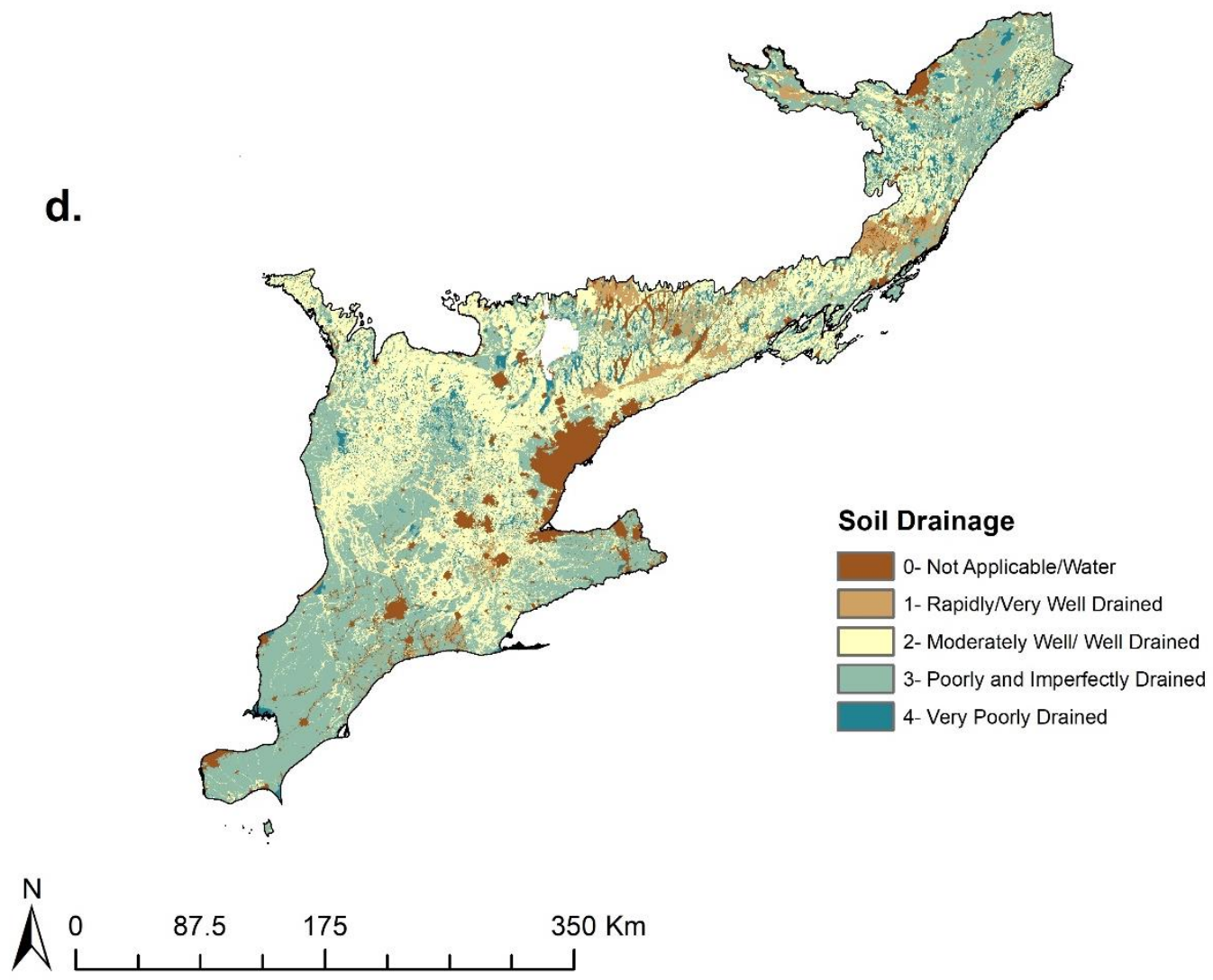

Figure 3.4: Spatial Distribution and Assigned Values: c. Built-up, d. Soil Drainage 
e.
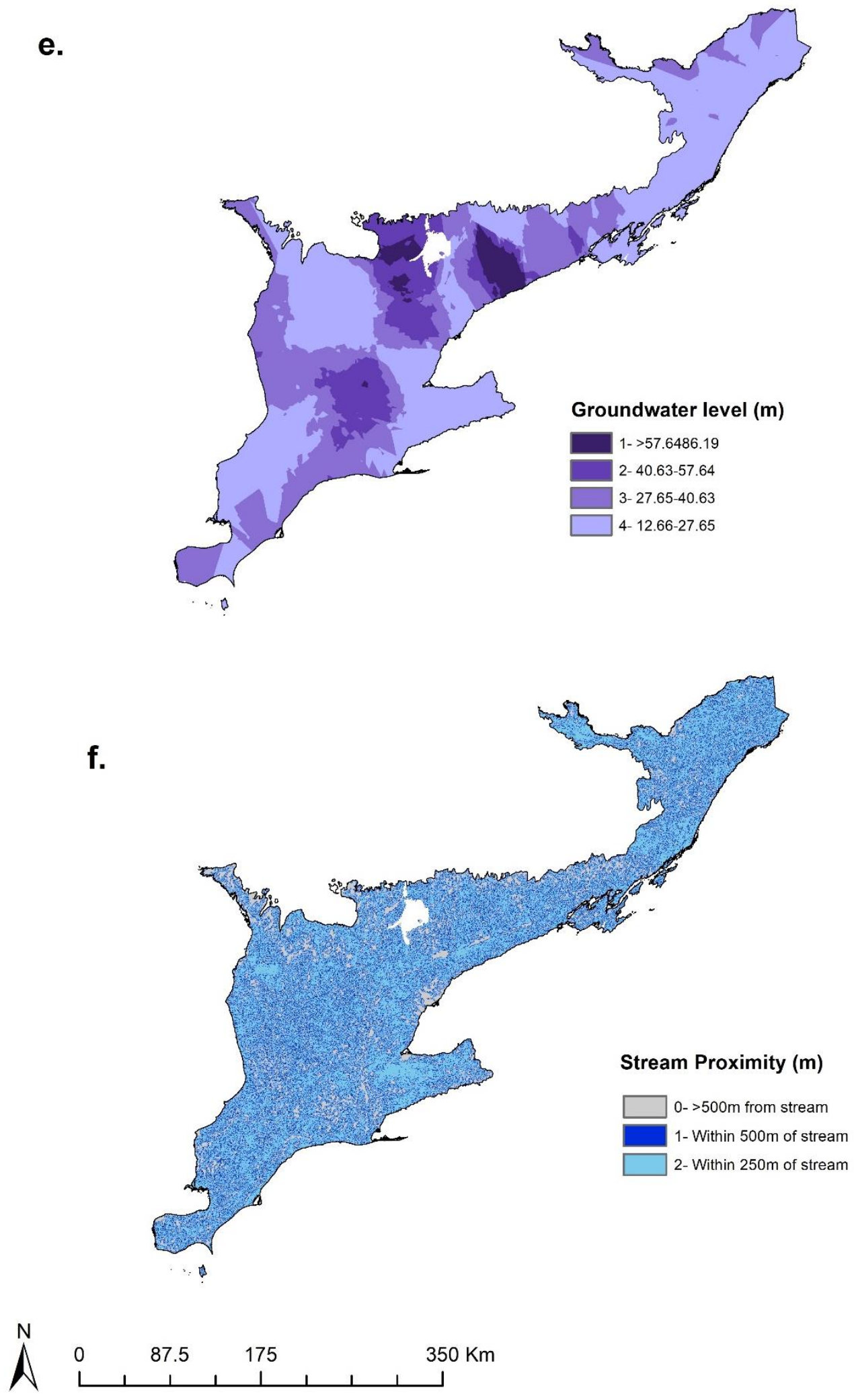

Figure 3.5: Spatial Distribution and Assigned Values: e. Groundwater level ( $m)$, f. Stream Proximity ( $m$ ) 


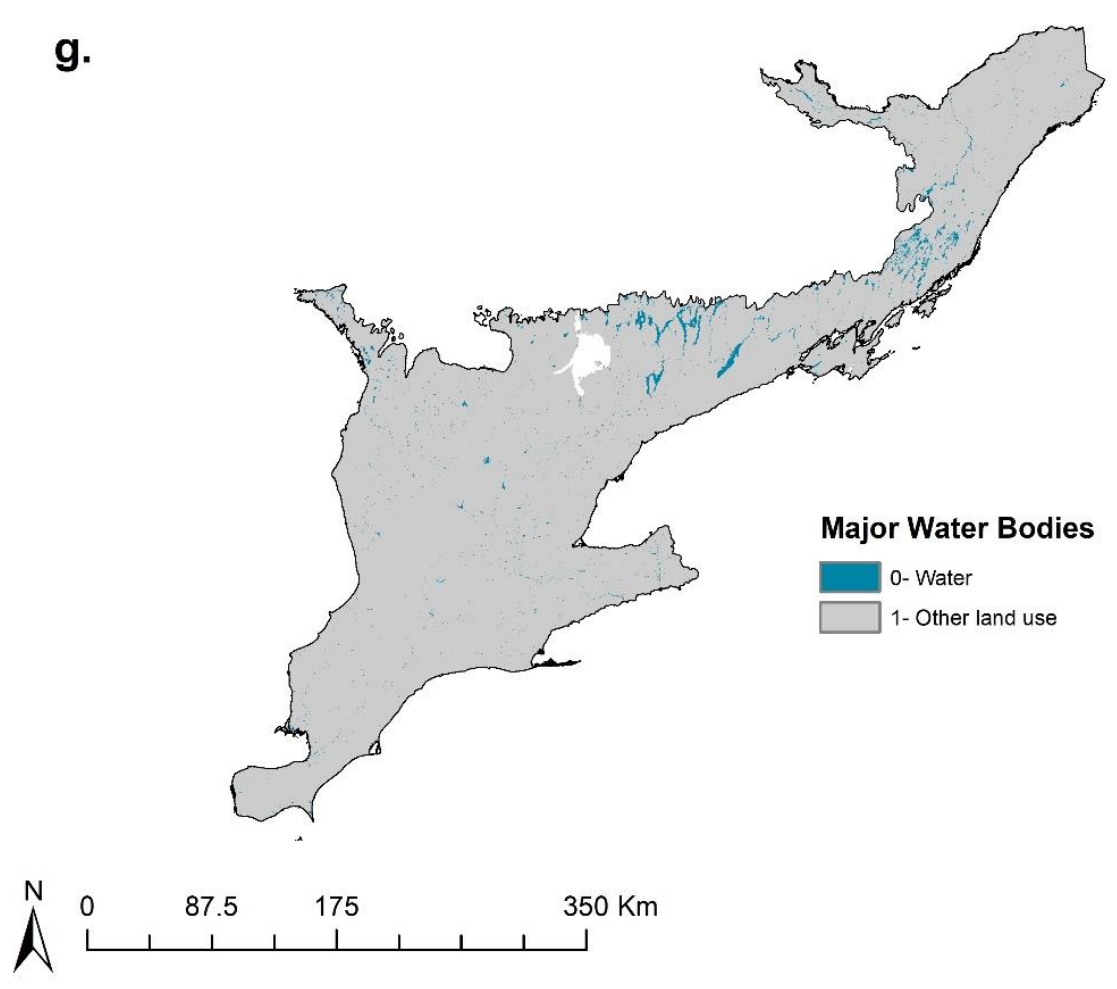

Figure 3.6: Spatial Distribution and Assigned Values: g. Major Water Bodies,

\subsubsection{Weighting}

The process of MCE is often used as part of planning initiatives (Atkinson et al., 2005; White \& Fennessy, 2005). In any situations where multiple criteria are evaluated, the relative importance of each variable determines its weight in the model, and therefore its influence on the result (Atkinson et al., 2005; Saaty, 1977). Similar studies on creating raster surfaces for environmental planning scenarios have used Saaty's (1977) AHP (Analytical Hierarchy Process) in order to rank the relative importance of criteria to the project (in this case wetland reconstruction) (Atkinson et al., 2005; White \& Fennessy, 2005).

For the purpose of this study, each variable's importance was ranked based on the number of times it appeared in the cited literatures MCEs for wetland reconstruction. This allowed every relationship to be classified on Saaty's nine-point reciprocal scale (Table 
3.3). Based on their relative counts, variables were classified as either equal $(+/-0)$, moderate $(+/-1)$, strong $(+/-2)$, very strong $(+/-3)$, or extreme $(+/->4)$ in their relative importance to the goal of wetland restoration (Table 3.3). These were then assigned the corresponding value if they were of more importance, or the reciprocal value if they were of less importance. For example, Agriculture appeared 5 times in the literature, and Streams had a count of 3 . The $+/-2$ difference in "count" resulted in Agriculture being strongly more important than Streams with a value of 5, and Streams earning the reciprocal value of 1/5.

Table 3.3: Saaty's AHP Reciprocal Importance Scale (1977) and relationship to literature "count"

\begin{tabular}{llll} 
Importance & Value & $\begin{array}{l}\text { Reciprocal } \\
\text { Value }\end{array}$ & $\begin{array}{l}\text { Difference in } \\
\text { "Count" }\end{array}$ \\
\hline Equal & 1 & 1 & None \\
Moderate & 3 & $1 / 3$ & $+/-1$ \\
Strong & 5 & $1 / 5$ & $+/-2$ \\
Very strong & 7 & $1 / 7$ & $+/-3$ \\
Extreme & 9 & $1 / 9$ & $+/->4$
\end{tabular}

The resulting pairwise comparison matrix (Table 3.4) represents each variable's relative importance for the purpose of weighting each in the index. Following the creation of the pairwise comparison matrix, each value must be normalized by the sum of its corresponding column. The criteria weights can then be calculated by summing each row and dividing by the number of variables $(n)$ (Table 3.5).

Table 3.4: Pairwise Comparison Matrix

\begin{tabular}{l|lllllll}
$\begin{array}{l}\text { Wetland } \\
\text { Restoration }\end{array}$ & $\begin{array}{l}\text { Soil } \\
\text { drainage }\end{array}$ & Streams & Waterbodies & $\begin{array}{l}\text { Ground- } \\
\text { water }\end{array}$ & Built-up & Agriculture & Slope \\
\hline Soil drainage & 1 & 7 & 9 & 9 & 9 & 3 & 7 \\
Stream & $1 / 7$ & 1 & 3 & 5 & 3 & $1 / 5$ & 1 \\
Water bodies & $1 / 9$ & $1 / 3$ & 1 & 3 & 1 & $1 / 7$ & $1 / 3$ \\
Groundwater & $1 / 9$ & $1 / 5$ & $1 / 3$ & 1 & $1 / 3$ & $1 / 9$ & $1 / 5$ \\
Built-up & $1 / 9$ & $1 / 3$ & 1 & 3 & 1 & $1 / 7$ & $1 / 3$ \\
Agriculture & $1 / 3$ & 5 & 7 & 9 & 7 & 1 & 5 \\
Slope & $1 / 7$ & 1 & 3 & 5 & 3 & $1 / 5$ & 1
\end{tabular}


Table 3.5: Normalized Pairwise Comparison Metrics

\begin{tabular}{|c|c|c|c|c|c|c|c|c|}
\hline $\begin{array}{l}\text { Wetland } \\
\text { Restoration }\end{array}$ & $\begin{array}{l}\text { Soil } \\
\text { drainage }\end{array}$ & Streams & Waterbodies & $\begin{array}{l}\text { Ground- } \\
\text { water }\end{array}$ & $\begin{array}{l}\text { Built- } \\
\text { up }\end{array}$ & Agriculture & Slope & $\begin{array}{l}\text { Criteria } \\
\text { weight }\end{array}$ \\
\hline Soil drainage & 0.5122 & 0.4709 & 0.3699 & 0.2571 & 0.3699 & 0.6254 & 0.4709 & 0.4395 \\
\hline Streams & 0.0732 & 0.0673 & 0.1233 & 0.1429 & 0.1233 & 0.0417 & 0.0673 & 0.0913 \\
\hline Waterbodies & 0.0569 & 0.0224 & 0.0411 & 0.0857 & 0.0411 & 0.0298 & 0.0224 & 0.0428 \\
\hline Groundwater & 0.0569 & 0.0135 & 0.0137 & 0.0286 & 0.0137 & 0.0232 & 0.0135 & 0.0233 \\
\hline Built-up & 0.0569 & 0.0224 & 0.0411 & 0.0857 & 0.0411 & 0.0298 & 0.0224 & 0.0428 \\
\hline Agriculture & 0.1707 & 0.3363 & 0.2877 & 0.2571 & 0.2877 & 0.2085 & 0.3363 & 0.2692 \\
\hline Slope & 0.0732 & 0.0673 & 0.1233 & 0.1429 & 0.1233 & 0.0417 & 0.0673 & 0.0913 \\
\hline Sum & 1.9524 & 14.8667 & 24.3333 & 35.0000 & 24.3333 & 4.7968 & 14.8667 & 1.0000 \\
\hline
\end{tabular}

The resulting weights (Table 3.6) from least to most important are: Soil drainage (43.9\%), Agriculture (26.9\%), Slope (9.1\%), Stream Proximity (9.1\%), Built-up (4.3\%), Major Waterbodies (4.3\%), and Groundwater (2.3\%).

Table 3.6: Final Criteria Classes, Weighting, and Ranking

\begin{tabular}{|c|c|c|c|c|}
\hline Variable & Symbol & Weight & Classes & Rank \\
\hline Agriculture & $\mathrm{Ag}$ & 0.269 & Agriculture & 1 \\
\hline \multirow[b]{2}{*}{ Built-up Area } & \multirow[b]{2}{*}{$\mathrm{Bu}$} & \multirow[t]{2}{*}{0.043} & Built up & 0 \\
\hline & & & Not & 1 \\
\hline \multirow{5}{*}{ Soil Drainage } & \multirow{5}{*}{$\mathrm{Sd}$} & \multirow[t]{5}{*}{0.439} & Very Poorly Drained & 4 \\
\hline & & & Poorly and Imperfectly Drained & 3 \\
\hline & & & Moderately Well / Well Drained & 2 \\
\hline & & & Rapidly / Very Rapidly Drained & 1 \\
\hline & & & Not Applicable/Water & 0 \\
\hline \multirow{4}{*}{$\begin{array}{l}\text { Groundwater } \\
\text { level (m) }\end{array}$} & \multirow{4}{*}{ Gw } & \multirow[t]{4}{*}{0.023} & $12.66-27.65$ & 4 \\
\hline & & & $27.65-40.63$ & 3 \\
\hline & & & $40.63-57.64$ & 2 \\
\hline & & & $57.64-86.19$ & 1 \\
\hline \multirow{2}{*}{$\begin{array}{l}\text { Major } \\
\text { waterbodies }\end{array}$} & \multirow{2}{*}{ Mw } & \multirow[t]{2}{*}{0.043} & Major Water Body & 0 \\
\hline & & & Not & 1 \\
\hline \multirow{3}{*}{ Slope (degrees) } & \multirow{3}{*}{ Sl } & \multirow[t]{3}{*}{0.091} & $<1.5$ & 2 \\
\hline & & & $1.5-4.75$ & 1 \\
\hline & & & $>4.75$ & 0 \\
\hline $\begin{array}{l}\text { Stream } \\
\text { Proximity }\end{array}$ & $\mathrm{Sp}$ & 0.091 & $\begin{array}{l}\text { Within } 500 \mathrm{~m} \\
\text { Within } 250 \mathrm{~m}\end{array}$ & $\begin{array}{l}1 \\
2\end{array}$ \\
\hline
\end{tabular}


For the resulting weights to be considered acceptable, the consistency within the weights must be checked (Saaty, 1977). The CR (Consistency Ratio) describes the level of inconsistency in the model. If $\mathrm{CR}<0.1$, then the weights are consistent. For this process, each value in the pairwise comparison matrix is multiplied by its criteria weight. When solved, the resulting consistency matrix can be used to calculate the weighted sum value (or sum of each row) (APPENDIX A). The weighted sum value is divided by the corresponding criteria weight, and the result is summed and averaged which $=\lambda_{\max }$. To calculate the CI (Consistency Index):

If $n=7$ and $(\mathrm{CI})=\left(\lambda_{\max }-n\right) /(n-1)$

Then $\mathrm{CI}=0.07164$

The Consistency Ratio is the Consistency Index divided by Random Index determined by $n$ (APPENDIX A) (Saaty, 1977).

$\mathrm{CR}=\mathrm{CI} / \mathrm{RI}($ Random Index $)$

$$
\mathrm{RI}=1.32 \text { when } n=7
$$

$=0.0543$

Therefore, the $\mathrm{CR}$ is 0.0543 and $<0.10$. The proportion of inconsistency is considered acceptable. The final ranking and weighting of each criterion represent their suitability to wetland landscapes and relative importance to wetland reconstruction (Table 3.6). 
The resulting index is as follows:

Wetland Reconstruction Site Selection $=$

$(A g * 0.269)+(B u * 0.043)+(S d * 0.439)+\left(G w^{*} * 0.023\right)+\left(M w^{*} * 0.043\right)+(S l * 0.091)+(S p * 0.091)$

\subsubsection{Model Validation}

To determine the potential accuracy of the index the resulting "best sites" were selected. These were any pixels with a suitability value over 1 standard deviation from the mean. Selected pixels were transformed into vector form for analysis. Using the overlay analysis tool "Intersect" in ArcMap 10.6.1, the most suitable sites were compared to existing wetlands, provincially significant wetlands designated by the OWES (Ontario Wetland Evaluation System), and a pre-settlement wetland extent created by DUC (Figures $4.2 \& 4.3)$. By comparing best sites with provincially significant wetlands, intersecting areas can be reasoned to be "valid" best sites, as they fit the OWES criteria. In addition, comparing best sites with the DUC historic wetland extent can validate best sites where wetlands are not longer present - as the landscape was once naturally suited for a wetland. 


\subsection{Results}

\subsection{Distribution of Suitable Sites}

Using variables from a variety of sources which best represent needs for wetland reconstruction, reflect natural wetland form, and make best use of ecosystem services, combined to create an index for which suitable sites for wetland reconstruction could be determined. These criteria were first ranked based on their suitability and then weighted based on their importance to wetland reconstruction as determined by the number of times they appeared in cited studies. After summing the aforementioned criteria, the resulting raster surface had a small suitability range of $0.047-2.571$ with a mean of 1.619 and a standard deviation of 0.504 . The distribution had a moderate negative skewness of -0.916 . The most suitable sites were represented by any pixel with a value over one standard deviation above the mean. This is any pixel with a value above 2.12 . If each cell is 0.25 ha at a $50 \mathrm{~m}$ resolution, then best sites have a combined area of 839,990 ha.

The criteria with the highest influence on the index were Soil drainage $(43.8 \%)$, Agriculture (26.9\%), Slope, and Proximity to Streams, both at 9.1\%. The remaining three criteria make up the remaining $20 \%$ of the model. The Built-up and Waterbodies classes are each weighted at $4.3 \%$, but due to their low binary ranking, cities and lakes received the lowest suitability scores. Spatially, best sites are clustered in the southern tip of the Mixedwood Plains and the Niagara Peninsula- which are both areas of homogenously low slope, agriculture, and poor/very poor drainage (Figure 4.1). Medium suitability is scattered throughout central and northern Ontario and reflects the spatial patterns of high groundwater depth, higher slopes, and well drained soils (Figures 3.3- 3.5 \& 4.1). 


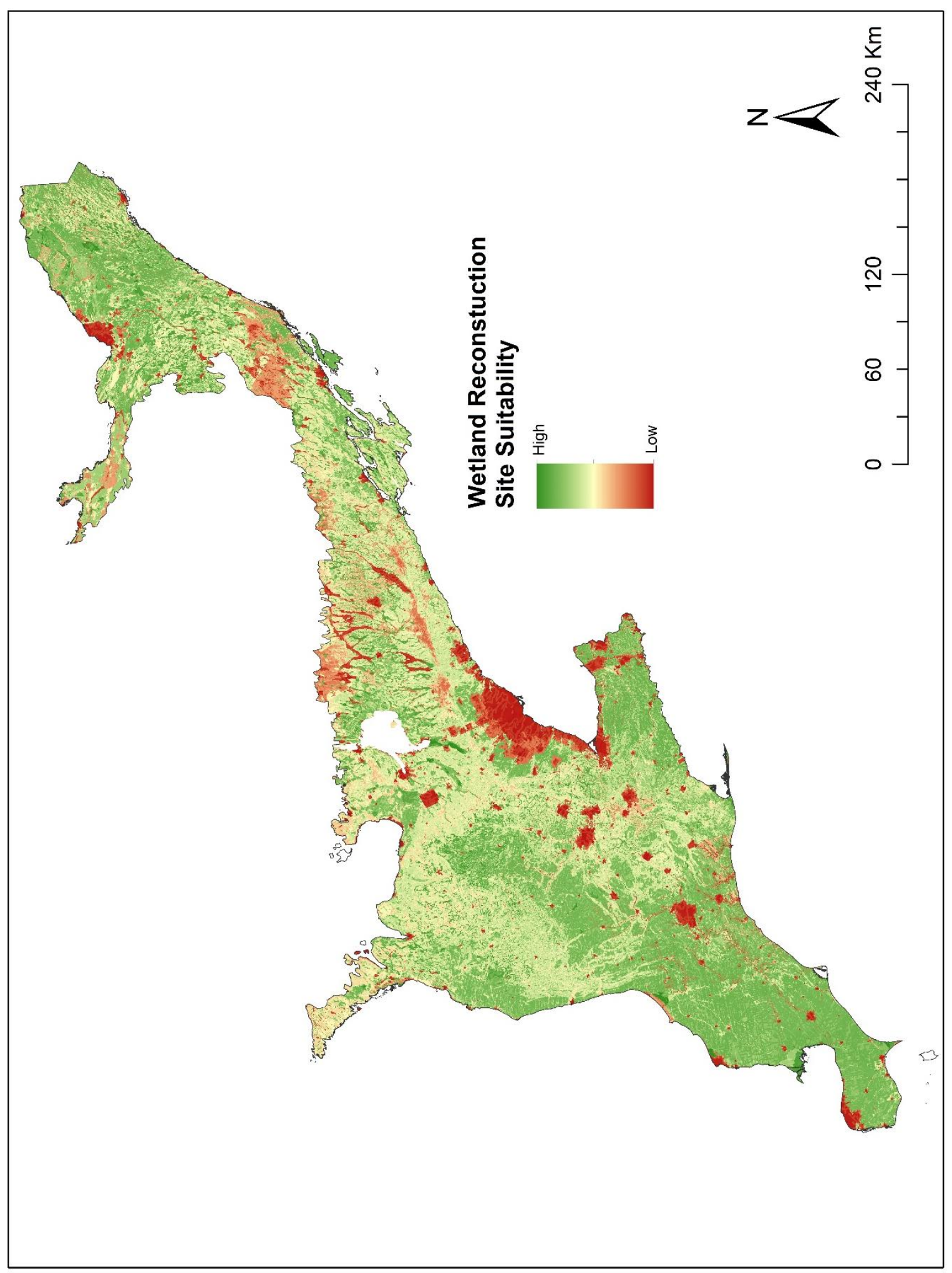

Figure 4.1: Wetland Reconstruction Site Suitability in Ontario Mixedwood Plains 


\subsection{Model Validation Results}

\subsubsection{Existing Wetlands Intersect}

When overlaid with all existing wetlands in the Mixedwood Plains region it was found that 299, 302.25 ha of area intersected of 839, 990.00 ha of best sites (Figure 4.2). Specifically, $35.63 \%$ of best sites were validated by existing wetlands. Census subdivisions in which the index selected the least number of existing wetlands include Haliburton, Kawartha Lakes, Peterborough and Hastings. The counties which make up the southern portion of the Mixedwood Plains (Essex, Lambton, and Kent) have seen a >90\% decrease in wetland area since settlement (Ducks Unlimited Canada, 2010). This area has a large cluster of best sites, but fewer existing wetlands. This pattern is also apparent in the northeast. 


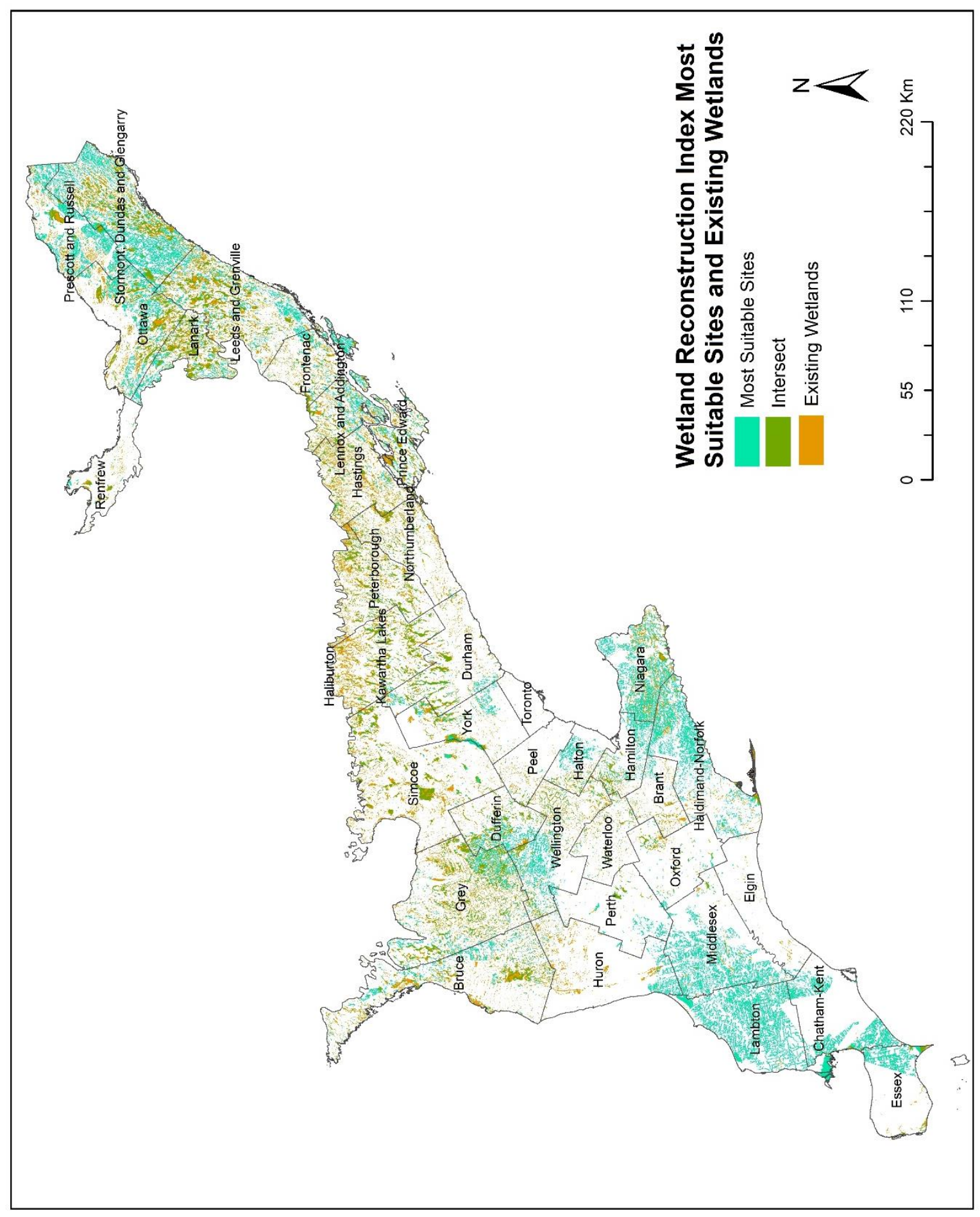

Figure 4.2: Wetland Site Suitability - Most Suitable Sites / and Existing Wetlands intersect by census subdivision 


\subsubsection{Provincially Significant Wetlands Intersect}

A total of $59.5 \%$ of provincially significant wetlands were identified by the wetland reconstruction site selection index. While the intersect does not represent an exact match between provincially significant wetlands and best sites, it is important to note that many of these spaces have undergone land cover change and are resisting their natural condition for the purpose of another land use (Figure 4.3).

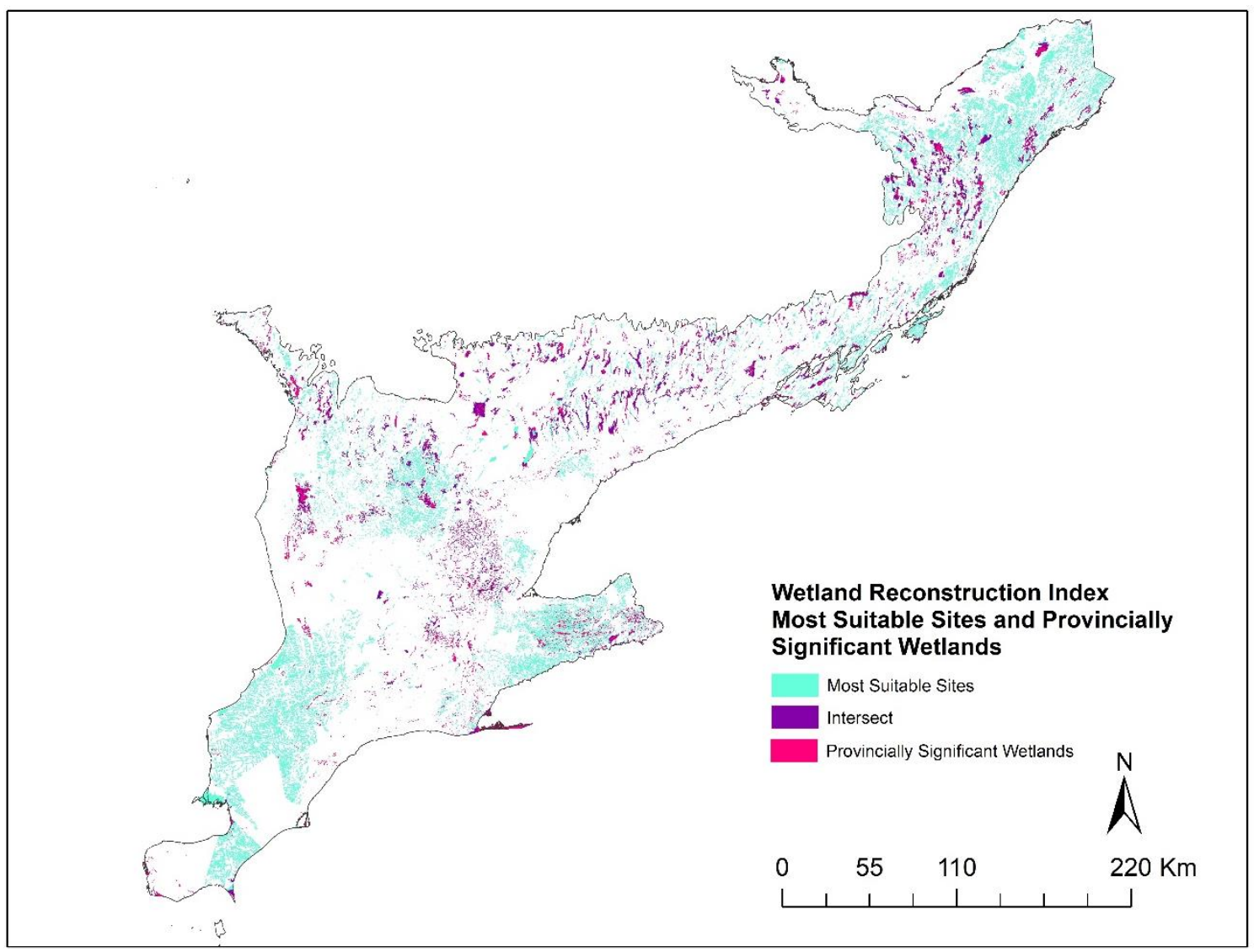

Figure 4.3: Wetland Reconstruction Site Suitability-Most Suitable Sites/ OWES Provincially Significant Wetland Comparison

\subsubsection{Pre-Settlement Wetlands Intersect}

The pre-settlement wetland extent has a much larger area than the provincially significant wetlands due to significant wetland loss. Large patches of best sites intersect 
with historic wetlands in the southern region, Niagara peninsula, and the northeast. As soil drainage was a significant consideration in the site suitability index and was also considered in the creation of DUC (2010) historic wetland extent, spatial patterns influenced by soil drainage are largely responsible for intersecting wetland sites (Figure 4.4).

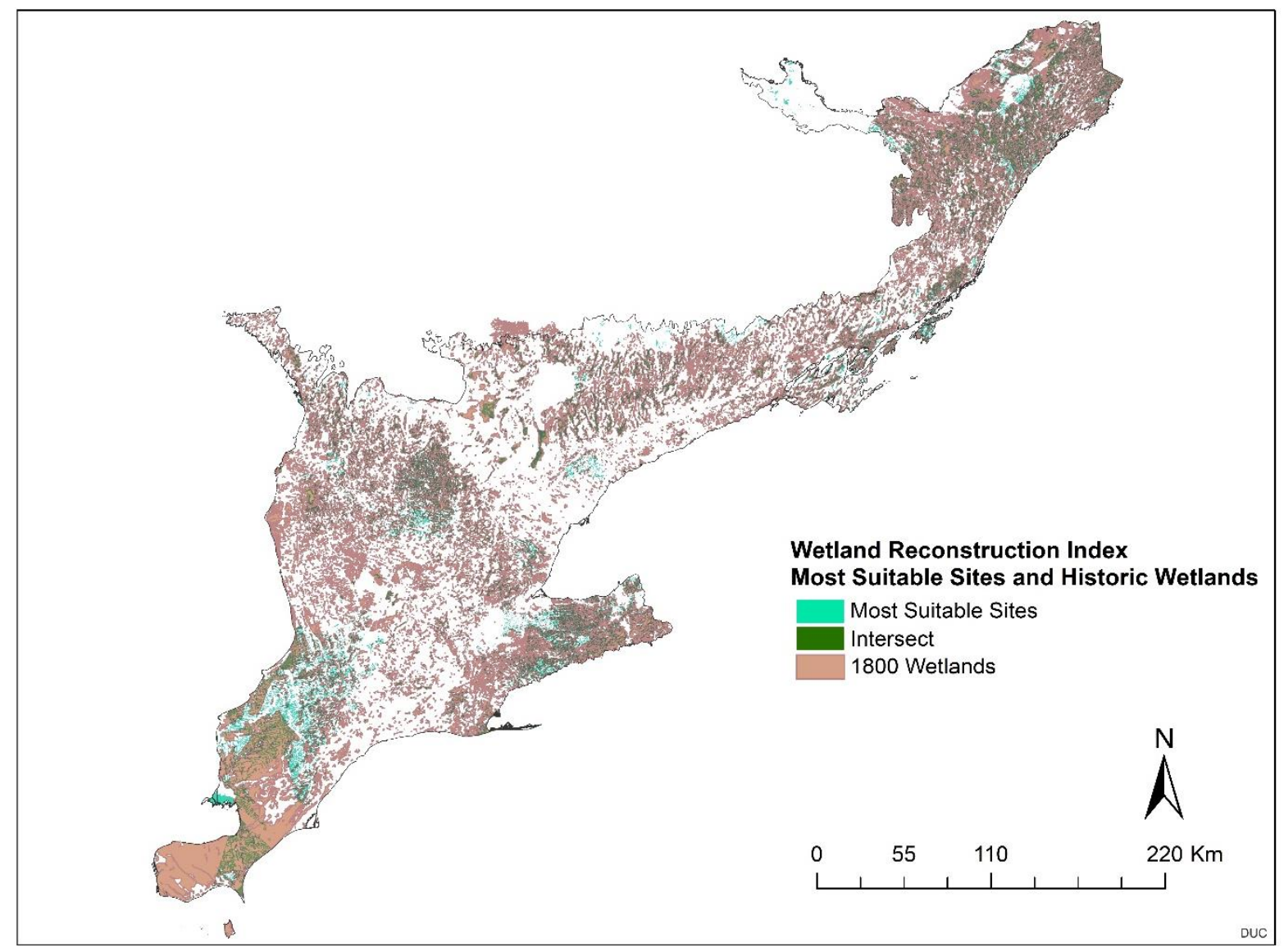

Figure 4.4: Wetland Reconstruction Site Suitability - Most Suitable Sites/DUC 1800s Historic Wetlands Comparison 


\subsection{Discussion and Conclusion}

\subsection{Discussion}

The Mixedwood Plains ecozone has seen a massive loss in wetlands throughout history. As organizations such as DUC and the Ontario MNRF attempt to halt and repair this loss, the need for large scale planning becomes apparent. The creation of a $50 \mathrm{~m}$ resolution suitability surface allows for site suitability to be considered at different scales. Using MCE techniques meant that various criteria could be evaluated simultaneously in a quantitative manner.

The chosen criteria fell into three overlapping categories: biophysical characteristics, land use, and ecosystem services. Biophysical variables include soil drainage, distance to streams, groundwater level, and slope. Land use includes major waterbodies, agriculture, and built-up. Lastly, ecosystem services are included through agriculture (areas which would benefit from biodiversity, water filtration, and flood mitigation) and soil drainage (frequently inundated soils which would benefit from flood mitigation). Best on relevant literature, each of the variables are important considerations for site suitability for wetlands.

This research demonstrates that many of the spaces in which wetlands have been removed from the landscape are still suitable for sustaining a wetland habitat. Areas with suitable sites, and few provincially significant wetlands, should be prioritized in wetland reconstruction planning. Suitable sites bordering provincially significant wetlands could represent opportunities to increase patch sizes and connectivity between existing habitats. Areas where best sites intersect with pre-settlement wetlands can be viewed opportunities 
to restore historic wetlands, as these sites still consider present-day obstacles such as infrastructure and were once successful wetlands.

\subsubsection{Limitations}

Limitations largely involve issues with data from various sources, of various quality. While the Mixedwood Plains ecozone includes Manitoulin island and surrounding smaller island, these had to be removed from the study due to a lack of data. However, the island was not included in other studies on the same study area such as DUC's Southern Ontario Wetland Analysis and therefore there was no loss of continuity in comparing the final suitability surface with the DUC historic extent. Additionally, some data sources were over a decade old, or were compilations of old and new data sets. These include the ARI land use, as well as the CLI, DSS. In order to account for lower resolution datasets, finer resolution data had to be simplified to the determined resolution of $50 \mathrm{~m}$. This resulted in some data loss. Lastly, the creation of a groundwater raster surface involved kriging interpolation, which provide a best estimate of groundwater depth.

\subsubsection{Recommendations}

With the growing quantity of higher resolution geospatial data, indices can be improved to include more criteria, at a finer scale. These could include data which represent additional ecosystem services such as biodiversity or recreation. Conversely, the use of remote sensing on current satellite imagery could allow for the classification of present land use and reduce issues with data from differing years and sources. Additionally, remote sensing could help to incorporate variables such as a wetness index, or farmland productivity to further identify best sites (Huang et al., 2010; Klemas, 2013). Two major studies on wetland extent on the Mixedwood Plains by Snell (1987) and Ducks Unlimited 
(2010) provided valuable groundwork for geospatial information on wetland loss in this ecozone. As Ontario planners and policy makers move towards the MNRF 2030 goals, these datasets should be consulted and updated more frequently to reflect wetland extent in Ontario.

To reiterate, the Ontario MNRF goals call for a reinstatement of wetland area and function to areas where wetland loss has been the greatest (Ontario MNRF, 2017). Ontario's historic wetland extent and where ecosystem services would contribute best must be considered to achieve these goals. Additionally, the best sites chosen by the wetland reconstruction site selection index should be investigated for land ownership, and the potential funding to buy and transform appropriate spaces should be allocated. Lastly, the involvement of expert opinion and stakeholders when determining the relative importance of each criterion could lend way to a less biased approach when determining weights, and create the most beneficial scenario (White \& Fennessy, 2005).

\subsection{Conclusion}

The use of GIS for decision making allows for the creation of replicable processes, which can be altered to suit the needs of the project or stakeholders. Considering multiple criteria allows for cost effective, environmentally conscious planning and by incorporating ecosystem services into these criteria, the most beneficial sites for a project may be chosen. The wetland reconstruction site suitability index provides a useful tool, which if utilized, could help to reach the Ontario MNRF wetland conservation goals. Returning wetlands to the Mixedwood Plains landscape could help to combat the effects of global change by introducing natural water filtration, increasing biodiversity, and reducing flood risk. By 
examining the historic condition of the landscape, sites which were once naturally suited to wetlands can be considered along side present day needs. 


\section{APPENDIX A}

Consistency Matrix (unnormalized X criteria weights)

\begin{tabular}{l|llllllll}
$\begin{array}{l}\text { Wetland } \\
\text { Reconstruction }\end{array}$ & $\begin{array}{l}\text { soil } \\
\text { drainage }\end{array}$ & streams & $\begin{array}{l}\text { water } \\
\text { bodies }\end{array}$ & $\begin{array}{l}\text { well- } \\
\text { depth }\end{array}$ & built-up & agriculture & slope & $\begin{array}{l}\text { weighted } \\
\text { sum value }\end{array}$ \\
\hline soil drainage & 0.4395 & 0.6388 & 0.3850 & 0.2095 & 0.3850 & 0.8076 & 0.6388 & 3.5042 \\
streams & 0.0628 & 0.0913 & 0.1283 & 0.1164 & 0.1283 & 0.0538 & 0.0913 & 0.6722 \\
water bodies & 0.0488 & 0.0304 & 0.0428 & 0.0698 & 0.0428 & 0.0385 & 0.0304 & 0.3035 \\
well-depth & 0.0488 & 0.0183 & 0.0143 & 0.0233 & 0.0143 & 0.0299 & 0.0183 & 0.1670 \\
built-up & 0.0488 & 0.0304 & 0.0428 & 0.0698 & 0.0428 & 0.0385 & 0.0304 & 0.3035 \\
agriculture & 0.1465 & 0.4563 & 0.2994 & 0.2095 & 0.2994 & 0.2692 & 0.4563 & 2.1367 \\
slope & 0.0628 & 0.0913 & 0.1283 & 0.1164 & 0.1283 & 0.0538 & 0.0913 & 0.6722
\end{tabular}

Random Index (Saaty, 1977)

\begin{tabular}{l|lllllllll}
$n$ & 2 & 3 & 4 & 5 & 6 & 7 & 8 & 9 & $\ldots$ \\
\hline RI & 0 & 0.58 & 0.90 & 1.12 & 1.24 & 1.32 & 1.41 & 1.45 & $\ldots$
\end{tabular}




\section{References:}

Atkinson, D. M., Deadman, P., Dudycha, D., \& Traynor, S. (2005). Multi-criteria evaluation and least cost path analysis for an arctic all-weather road. Applied Geography, 25(4), 287-307. https://doi.org/10.1016/j.apgeog.2005.08.001

Bellard, C., Leclerc, C., Leroy, B., Bakkenes, M., Veloz, S., Thuiller, W., \& Courchamp, F. (2014). Vulnerability of biodiversity hotspots to global change: Biodiversity hotspots and global change. Global Ecology and Biogeography, 23(12), 13761386. https://doi.org/10.1111/geb.12228

Bradford, A. (2016). Averting degradation of southern Ontario wetlands due to hydrologic alterations associated with development. Canadian Water Resources Journal / Revue Canadienne Des Ressources Hydriques, 41(4), 543-553. https://doi.org/10.1080/07011784.2015.1119061

Classens, M. (2017). The transformation of the Holland Marsh and the dynamics of wetland loss: A historical political ecological approach. Journal of Environmental Studies and Sciences, 7(4), 507-518. https://doi.org/10.1007/s13412-016-0407-4

Classens, M. (2018). The Matter of Matter: Making Property in the Holland Marsh. Society \& Natural Resources, $\quad$ 31(2), 246-259. https://doi.org/10.1080/08941920.2017.1364453

Darwiche-Criado, N., Sorando, R., Eismann, S. G., \& Comín, F. A. (2017). Comparing Two Multi-Criteria Methods for Prioritizing Wetland Restoration and Creation Sites Based on Ecological, Biophysical and Socio-Economic Factors. Water Resources Management, 31(4), 1227-1241. https://doi.org/10.1007/s11269-017$1572-2$ 
Ducks Unlimited Canada. (2010). Southern Ontario Wetland Conversion Analysis. Retrieved from: https://www.ducks.ca/assets/2010/10/duc_ontariowca_optimized.pdf

Giblett, R. (2014). Canadian Wetlands: Places and People. Retrieved from http://ebookcentral.proquest.com/lib/ryerson/detail.action?docID=1840925

Haddad, N. M., Brudvig, L. A., Clobert, J., Davies, K. F., Gonzalez, A., Holt, R. D., ... Townshend, J. R. (2015). Habitat fragmentation and its lasting impact on Earth's $\begin{array}{llll}\text { ecosystems. } & \text { Science } & \text { Advances, } & \text { l(2), }\end{array}$ https://doi.org/10.1126/sciadv.1500052

Horvath, E. K., Christensen, J. R., Mehaffey, M. H., \& Neale, A. C. (2017). Building a potential wetland restoration indicator for the contiguous United States. Ecological Indicators, 83(Complete), 463-473. https://doi.org/10.1016/j.ecolind.2017.07.026

Huang, N., Wang, Z., Liu, D., \& Niu, Z. (2010). Selecting Sites for Converting Farmlands to Wetlands in the Sanjiang Plain, Northeast China, Based on Remote Sensing and GIS. Environmental Management, 46(5), 790-800. https://doi.org/10.1007/s00267-010-9547-6

Khalili, K. (2014). Comparison of Geostatistical Methods for Interpolation Groundwater Level (Case study: Lake Urmia Basin).

Klemas, V. (2011). Remote Sensing of Wetlands: Case Studies Comparing Practical Techniques. Journal of Coastal Research, 27(3), 418-427. Retrieved from JSTOR.

Klemas, V. (2013). Using Remote Sensing to Select and Monitor Wetland Restoration Sites: An Overview. Journal of Coastal Research, 29(4), 958-970. Retrieved from JSTOR. 
Kumar, V., \& Remadevi, D. (2006). Kriging of Groundwater Levels - A Case Study. Journal of Spatial Hydrology, 6(1). Retrieved from http://www.spatialhydrology.net/index.php/JOSH/article/view/48

Lovejoy, T. E., Hannah, L., \& Wilson, E. O. (2019). Biodiversity and Climate Change: $\begin{array}{llll}\text { Transforming the Biosphere. } & \text { Retrieved }\end{array}$ http://ebookcentral.proquest.com/lib/ryerson/detail.action?docID=5607598

National Wetlands Working Group (Ed.). (1987). The Canadian wetland classification system. Ottawa? Inland Waters/Lands Directorate, Environment Canada.

Odgaard, M. V., Turner, K. G., Bøcher, P. K., Svenning, J.-C., \& Dalgaard, T. (2017). A multi-criteria, ecosystem-service value method used to assess catchment suitability for potential wetland reconstruction in Denmark. Ecological Indicators, 77(Complete), 151-165. https://doi.org/10.1016/j.ecolind.2016.12.001

Ontario Ministry of Natural Resources and Forestry. (2017). A Wetland Conservation Strategy for Ontario 2017-2030. Queen's Printer for Ontario. Toronto, ON. 52 pp

Saaty, T. (1977). A scaling method for priorities in hierarchical structures. Journal of Mathematical Psychology, 15(3), 234-281. https://doi.org/10.1016/00222496(77)90033-5

Shaker, R. R., \& Sirodoev, I. G. (2016). Assessing sustainable development across Moldova using household and property composition indicators. Habitat International, 55, 192-204. https://doi.org/10.1016/j.habitatint.2016.03.005

Shaker, R. R., Yakubov, A. D., Nick, S. M., Vennie-Vollrath, E., Ehlinger, T. J., \& Forsythe, K. W. (2017). Predicting aquatic invasion in Adirondack lakes: A spatial 
analysis of lake and landscape characteristics. Ecosphere, 8(3), e01723. https://doi.org/10.1002/ecs2.1723

Sivakumar, R., \& Ghosh, S. (2016). Wetland spatial dynamics and mitigation study: An integrated remote sensing and GIS approach. Natural Hazards, 80(2), 975-995. https://doi.org/10.1007/s11069-015-2007-0

Snell, E. A. (1987). Wetland distribution and conversion in southern Ontario. Ottawa: Canada Land Use Monitoring Program.

Venter, O., Sanderson, E. W., Magrach, A., Allan, J. R., Beher, J., Jones, K. R., ... Watson, J. E. M. (2016). Sixteen years of change in the global terrestrial human footprint and implications for biodiversity conservation. Nature Communications; London, 7, 12558. http://dx.doi.org.ezproxy.lib.ryerson.ca/10.1038/ncomms 12558

Wetland conservation strategy. (2017, June 16). Retrieved April 22, 2019, from Ontario.ca website: https://www.ontario.ca/page/wetland-conservation-strategy

White, D., \& Fennessy, S. (2005). Modeling the suitability of wetland restoration potential at the watershed scale. Ecological Engineering, 24(4), 359-377. https://doi.org/10.1016/j.ecoleng.2005.01.012

Yalcin, S., \& Leroux, S. J. (2018). An empirical test of the relative and combined effects of land-cover and climate change on local colonization and extinction. Global Change Biology, 24(8), 3849-3861. https://doi.org/10.1111/gcb.14169 